NBER WORKING PAPER SERIES

\title{
BUSINESS GROUPS AND THE INCORPORATION OF FIRM-SPECIFIC SHOCKS INTO STOCK PRICES
}

\author{
Mara Faccio \\ Randall Morck \\ M. Deniz Yavuz \\ Working Paper 25908 \\ http://www.nber.org/papers/w25908 \\ NATIONAL BUREAU OF ECONOMIC RESEARCH \\ 1050 Massachusetts Avenue \\ Cambridge, MA 02138 \\ May 2019
}

We thank participants at ASU Sonoran Winter Finance Conference (2019), Erasmus University Rotterdam, George Mason University, INSEAD, KU Leuven, Maastricht University, Northeastern University, Purdue University, Tilburg University, the University of Illinois at Chicago, Heitor Almeida (discussant), George Aragon, Radhakrishnan Gopalan, Jeff Pontiff, and Kelly Shue for comments and earlier discussions. We thank Mitch Johnston, Chen Zhaojing and Shrijata Chattopadhyay for excellent research assistance. The views expressed herein are those of the authors and do not necessarily reflect the views of the National Bureau of Economic Research.

NBER working papers are circulated for discussion and comment purposes. They have not been peer-reviewed or been subject to the review by the NBER Board of Directors that accompanies official NBER publications.

(C) 2019 by Mara Faccio, Randall Morck, and M. Deniz Yavuz. All rights reserved. Short sections of text, not to exceed two paragraphs, may be quoted without explicit permission provided that full credit, including $\left({ }^{\circ}\right.$ notice, is given to the source. 
Business Groups and the Incorporation of Firm-specific Shocks into Stock Prices

Mara Faccio, Randall Morck, and M. Deniz Yavuz

NBER Working Paper No. 25908

May 2019

JEL No. G14,G15,G32,G34,M41

\title{
ABSTRACT
}

In lower-income economies, stocks exhibit less idiosyncratic volatility and business groups are more prevalent. This study connects these two findings by showing that business group affiliated firms' stock returns exhibit less idiosyncratic volatility than do the returns of otherwise similar unaffiliated firms. Global commodity price shocks are common shocks that contribute to firmlevel idiosyncratic risk because they affect industries heterogeneously. Idiosyncratic components of commodity shocks are incorporated less into idiosyncratic returns of group affiliates than unaffiliated firms in the same industry and economy. Identification follows from difference-indifference tests exploiting successful and matched-exogenously-failed control block transactions.

\author{
Mara Faccio \\ Krannert School of Management \\ Purdue University \\ 403 W. State Street \\ West Lafayette, IN 47907 \\ and NBER \\ mfaccio@purdue.edu \\ Randall Morck \\ Faculty of Business \\ University of Alberta \\ Edmonton, AB T6G 2R6 \\ CANADA \\ and NBER \\ randall.morck@ualberta.ca
}

\author{
M. Deniz Yavuz \\ Krannert Graduate School of Management \\ Purdue University \\ 403 W. State Street \\ West Lafayette, IN 47907-2056 \\ myavuz@purdue.edu
}




\section{Introduction}

Stocks move more synchronously (Morck et al., 2000) in less developed economies and in economies that allocate capital less efficiently across industries (Wurgler, 2000). Business groups are also more important in less developed economies (La Porta et al., 1999; Fogel 2006; Masulis et al. 2011) and are associated with compromised economy-level capital allocation efficiency (Almeida and Wolfenzon 2006b; Morck, Yavuz and Yeung 2011). This study connects these two lines of research by showing that business group affiliated firms' stocks move less idiosyncratically than the stocks of otherwise similar unaffiliated firms in the same industries subjected to the same commodity price shocks.

Idiosyncratic shocks are more important in some firms and economies than in others due more active risk taking, entrepreneurship and creative destruction (Chun et al.,2011; Bartram, Brown and Stulz, 2012) or a more competitive environment (Irvine and Pontiff, 2009). Differences in the importance of observed idiosyncratic shocks may also reflect differences in transparency and insiders' private-benefits (Jin and Myers, 2006), the marginal costs and benefits of producing firm-specific information (Veldkamp, 2006) and media coverage (Kim, Yu and Zhang, 2016). Numerous studies, surveyed in Morck et al. (2013), support all of these explanations with the common theme being higher firm-specific return volatility reflecting better functioning financial systems in more developed economies. Panel A of Figure 1 summarizes this stylized fact.

At the same time, the prevalence of business groups, defined here as collections of firms under common control through equity blocks, correlates negatively with economic development. This pattern, evident in the data, is plotted in Panel B of Figure 1. Business groups can shift income from firms with excess free cash flow to firms with unfinanced profitable investments 
(Almeida and Wolfenzon, 2006a). Business groups may also shift income to fund private benefits for their top insiders (Johnson et al., 1999; Bertrand, Mehta and Mullainathan, 2002), and Jin and Myers (2006) argue that shifting firm-specific income to corporate insiders is less observable to public shareholders. Business groups may also prop up ill-run affiliates (Morck and Nakamura, 1999) and share risks (Hoshi, Kashyap and Scharfstein, 1990, 1991; Friedman, Johnson and Mitton, 2003; Khanna and Yafeh, 2005; Gopalan, Nanda, and Seru, 2007). Investors, expecting business groups to behave in any or all of these ways, may rationally expect idiosyncratic shocks to have less impact on the share prices of a group affiliate than on the share prices of an otherwise comparable unaffiliated firm.

To understand whether group affiliated firms and unaffiliated firms incorporate firmspecific shocks differently and avoid explanations contaminated by differences in shocks and/or their observability, one would ideally like to observe the responses of group affiliated and unaffiliated firms to the same shock, which would be observable by all market participants. This is precisely what we do in this paper. We test whether or not global commodity price shocks, observable simultaneously to all investors throughout the world, have different impacts on the share prices of group-affiliated and unaffiliated firms in commodity-sensitive sectors.

This requires matching commodities to industries - - and thus to firms. We do this in three main ways. One approach uses statistically estimated out-of-sample sensitivity of U.S. industries to commodity shocks, emulating Rajan and Zingales' (1998) methodology for flagging external finance-dependent sectors. The major advantage of the statistical method is that it gauges an industry's sensitivity to commodity price-related shocks through all possible channels, including supply and demand effects, linkages to untraded commodities or other factors (Anderson and Danthine, 1981). The second approach uses constrained statistical matches, those 
that best satisfy the criteria of the statistical method subject to the industry being a direct users or producers of the commodity linked to it. The third approach simply links industries to commodities that constitute large fractions of their inputs or outputs by using Bureau of Economic Analysis (BEA) input-output tables. Because business groups are relatively unimportant in the US (La Porta et al., 1999; Masulis et al. 2011), the statistical method and constrained statistical method mitigate attenuation bias due to group affiliated firms possibly being less responsive to commodity shocks. The third method sidelines this problem by focusing on commodity inputs and outputs rather than estimating sensitivities in sample.

We find that the idiosyncratic returns of business group affiliated firms are less responsive to idiosyncratic commodity price shocks than are the idiosyncratic returns of unaffiliated firms after controlling for time-varying country-industry level latent variables. The results are not driven by firm-level observable characteristics such as hedging, diversification across industries, its equity ownership of other firms, leverage, size or R\&D activity. The results are robust to battery of tests that vary industry-commodity matching, business group affiliate identification, regression specifications, samples and the asset pricing model used in calculation of idiosyncratic returns.

Further identification follows from difference-in-difference tests exploiting changes in group affiliation, control block acquisitions and failed control block bids. The stocks of previously unaffiliated firms that become group affiliated immediately become less sensitive to such commodity price shocks compared to a matched group of firms not changing group affiliation and the stocks of previously affiliated firms that cease to be group affiliated immediately become more sensitive to such commodity price shocks compared to a matched group of firms not changing group affiliation. Potential selection problems in control block 
transactions are precluded by comparing successful acquisition attempts with matched control block bids that failed for defensibly exogenous reasons (Seru, 2014), which reaffirms our results.

We also show that the stocks of group firms' in other sectors, including sectors that are not sensitive to commodity shocks, react to idiosyncratic commodity shocks affecting industries in which other firms in the same business group operate. These results are consistent with investors expecting risk sharing or income shifting within business group firms to attenuate firmspecific stock return volatility associated with idiosyncratic commodity shocks.

If group affiliation attenuates share price responses to commodity shocks, it may well attenuate share price responses to other firm-specific shocks and increase stock price synchronicity across all the firms in the business group. Indeed, Khanna and Thomas (2009) report significantly elevated synchronicity in the stock returns of Chilean firms with director interlocks and equity ties. Attenuated firm-specific shocks would increase a stock's synchronicity with its market measured by its market model $R^{2}$. Firm-level tests show that business group affiliates' stocks have higher synchronicity with their markets than do otherwise similar unaffiliated firms. Finally, Panel $\mathrm{C}$ of Figure 1 shows that stock returns are more synchronous in economies where more firms are group affiliated. Thus, we show business group prevalence to be a complementary explanation, in addition to others surveyed by Morck et al. (2013), to market level stock synchronicity.

Finally, our results expose basic issues regarding the fundamental role of the stock market in capitalizing firm-specific information into stock prices (Grossman 1976) and allocating resources to their highest value uses (Tobin 1984). Group firms' stocks moving less than otherwise similar unaffiliated firms' stocks on the same commodity price shock can be viewed as the market efficiently reflecting information about real differences in how that shock 
is expected to affect the two firms. Thus our paper highlights how expected intragroup resource and risk reallocation reduce group firms' idiosyncratic stock return volatility from commodity shocks and presumably from non-systematic shocks in general. This leaves each individual group firm's stock price less able to provide feedback to inform its capital providers and managers (Bond et al. 2012).

\section{Data and Methodology}

There are several steps in the construction of our sample: First, we identify group affiliated firms as outlined below. Next, we calculate idiosyncratic components of stock returns and idiosyncratic components of commodity shocks. Finally, we identify which industries (and hence firms) would be sensitive to shocks to the prices of key commodities using three different methods of matching.

\subsection{Group Affiliation}

Ownership data for publicly traded firms worldwide are from three sources: Worldscope for 1993 through 2009; Thomson Reuters Ownership for 2005 through 2012; and Datastream Asset 4 Universe for 2002 through $2013 .{ }^{1}$ For an economy to be included in our sample, we require that it have at least 50 publicly traded firms for which we have ownership data at any time during the entire sample period. This leaves a sample of 43 economies.

Each of these data sources provides the name and the cash flow (i.e., ownership) rights of each firm's largest shareholder. We presume that the largest blockholder has a controlling stake if her ownership stake in the firm is at least $20 \%$. This cut-off is also employed by La Porta et al.

\footnotetext{
${ }^{1}$ All three datasets have been discontinued.
} 
(1999) to infer control. ${ }^{2}$ Using this relatively high ownership threshold minimizes problems due to cross-economy differences in the precise threshold that triggers ownership disclosure. Our data provide ownership stakes, not voting control stakes, which depend on control enhancement devices such as dual class shares, golden shares, reserved board seats, or pyramiding via unlisted affiliates. This almost certainly leads to misclassifying some group affiliates as unaffiliated, and therefore introduces an attenuation bias, biasing point coefficient estimates on measures of group affiliation towards zero.

Controlling shareholders are classified as governments, corporations, investment funds or individuals (including families) using lists of words and abbreviations commonly found in the names of each sort of entities. Faccio, Marchica, and Mura (2011) provide a list of terms commonly found in the names of government shareholders (in various languages) and Faccio and O’Brien (2015) provide an analogous list for corporate entities. For example, a controlling shareholder whose name contains the term "Ltd", or its equivalent in another language, is presumed a corporation; while a controlling shareholder whose name contains the term "municipal" is presumed a government entity. Investment funds are flagged using an analogous list we develop for this purpose. Terms such as "fund" identify investment funds. ${ }^{3}$ Any

${ }^{2}$ Robustness tests in Section 5.2 alternatively use a $15 \%$ ownership threshold.

3 In some countries, business families control business groups via pension funds - e.g. Brazil (Perkins et al., 2014), closed-end mutual funds - e.g. Sweden (Högfeldt, 2005), or other institutional investment funds. In recent years, increasing numbers of US firms have investment funds as common equity block holders (Gilje, Gormley and Levit, 2018). The Investment Companies Act of 1940 proscribes US investment companies from intervening in listed firms' management decisions except as shareholders operating via channels legally open to shareholders, so the effects we explore are less likely to be evident in such cases. Disputed findings (e.g., Rock et al., 2017; Schmalz, 2018) nonetheless associate common institutional investor ownership with coordinated corporate strategies, notably price fixing. To avoid counting US ETFs or investment funds as controlling shareholders in defining business groups, common blockholders are screened for English terms associated with institutional investors (listed in Appendix A3). This presumes English terms flag US-based institutional investors and miss those based in other countries. Robustness tests (not shown) that retain investment companies associated with a business family (using a list of keywords like "family", "estate" etc.) as common controlling shareholders for the purpose of detecting business groups yields results (not shown) similar to those in the tables. The list of words used to identify investment funds is available on request. 
controlling shareholder not classified as a government, corporation or as investment fund is presumed an individual.

Firms whose controlling shareholder is a government entity are dropped from the sample because state owned enterprises' (SOEs) soft budget constraints (Kornai, 1986) could affect the link between their fundamentals and stock returns. SOEs' public shareholders might anticipate bailouts to smooth earnings fluctuations; and natural monopoly SOEs might pass shocks to consumers, partially immunizing shareholders. SOE shares' reactions may thus resemble those of group affiliates even if the SOEs are not formal affiliates of state-controlled groups of listed firms, such as existed in Austria and Italy until recently and remain important in China.

We classify a firm as group affiliated if (1) its controlling shareholder is a corporation; (2) its controlling shareholder is an individual who controls at least one other firm in our sample; or (3) the firm itself is the controlling shareholder of at least one other firm in our sample. All other firms, including those controlled by investment funds, are designated unaffiliated. This classification algorithm follows prior studies (e.g. Faccio, Lang and Young, 2001; Bae, Kang, and Kim, 2002; Bertrand, Mehta, and Mullainathan, 2002; Baek, Kang, and Lee, 2006; Masulis, Pham and Zein, 2011) in defining business groups as collections of separate legal entities under common control through equity blocks.

To identify controlling shareholders who own control blocks in multiple firms in the sample, the names of controlling shareholders are matched by Levenshtein (1965) distance: the minimum number of single character edits (excluding punctuation, multiple consecutive spaces, and spaces at the beginning or at the end) required to change one name into the other, normalized by the length of the shorter name. If the Levenshtein distance between two names is $20 \%$ or less, the algorithm infers a match. The algorithm allows for minor name variations that exact 
matching would miss, but is far from perfect.

False and missed matches are inevitable. The vagaries of languages and the complexities of control chains (see Almeida et al., 2011) combined with a relatively stringent (20\%) threshold likely leave missed matches predominating. Our approach misses group affiliates controlled via multiple control chain that sum to over $20 \%$ if each falls below that threshold as well as those controlled via the control enhancement devices mentioned above. This further potential misclassification of group affiliates as unaffiliated also adds attenuation bias in the tests below. An opposite problem arises if we misidentify targets in the process of being acquired or divisions in the process of being divested as group affiliates. This is a potentially more serious problem in economies, such as the US, with more merger and divestiture activity. ${ }^{4}$

This yields 55,671 unique firms and 390,186 firm-years of ownership data. Table 1 Panel A summarizes firm-year observations classified as group affiliated versus unaffiliated, by economy. Consistent with prior studies, business groups are prevalent around the world, and more prevalent in some economies than others. For example, group affiliated firms account for large fraction of firms in Chile, Italy, Hong Kong and Peru, but lower fractions of firms in Taiwan, the United States, the United Kingdom and Canada. Stulz (2005) shows how the percentage of shares held by control block holders varies across economies. Although presence of a control blockholder does not imply business group affiliation, Stulz's (2005) ranking of economies by percentage of shares held by blockholders is consistent with our ranking by the prevalence of business groups: Taiwan, the United States, the United Kingdom and Canada rank low, while Peru and Chile rank high.

\footnotetext{
${ }^{4}$ Many instances of listed US firms holding equity blocks exceeding $20 \%$ in other listed firms may be corporate control transactions in progress. Acquirers often begin with toehold acquisitions followed by bids for all the target's shares (Betton et al., 2009). Lasting toeholds exist, for example between firms undertaking a joint venture, but the stakes are typically far smaller than $20 \%$ and do not indicate common control (Ouimet, 2013).
} 


\subsection{Firm-level control variables}

Table 1 Panel B summarizes the means of key firm-level characteristics across group affiliated and unaffiliated firms. The panel reports statistics both from the entire sample and from the sample excluding US firms. We report both because in some tests we exclude US firms as explained below. The firm diversification variable is minus one times the Herfindahl index of the firm's industrial focus, measured using Datastream annual segment-level revenues in up to ten product segments, so a value of minus one indicates an undiversified firm. ${ }^{5}$ Leverage is book value of total debt divided by book value of total assets. Hedging activity is an indicator variable equal to 1 if Datastream reports that the firm discloses financial data associated with hedging or derivative usage: these are "Comprehensive Income Hedging Gain/Loss", "Unrealized Valuation Gains/Losses Hedges/Derivatives", "Derivative Assets Current", "Derivative Liabilities Current", "Derivative Assets Non-Current", "Derivative Liabilities Non-Current". The proxies for firm size, market capitalization in million USD or total assets in thousand USD, enter the regressions as logs. $R \& D$ activity is $R \& D$ expenses over total assets. If $R \& D$ expenses are missing, R\&D spending is presumed insubstantial and set to zero.

Compared to unaffiliated firms, group affiliated firms are on average smaller, more leveraged, less invested in $\mathrm{R} \& \mathrm{D}$, more diversified, and less actively hedging. The tests below

must thus allow for these differences between group affiliated and unaffiliated firms in contrasting their responses to idiosyncratic shocks.

\subsection{Firm-specific Shocks}

\footnotetext{
5 If segment-level sales are unreported we assume the firm's sales are in one segment.
} 
For each firm, Datastream weekly (Wednesday-to-Wednesday) total returns are used. These include price changes and dividends and are adjusted for stock splits, reverse splits, and stock dividends. Stocks that trade for fewer than 12 weeks during our sample period are dropped, as are firm-week observations with three or more missing daily returns in the week. Following the prior literature, in particular Jin and Myers (2005), we use a version of global CAPM to define firm specific shocks. Since we investigate the link between two lines of prior research, for the sake of transparency, we believe it useful to avoid changing the methodology. However, in robustness tests, we consider an alternative asset pricing model based on Fama and French's (2015) global 5-factor model.

Firm-specific shocks are the residuals from separate regressions for each firm in the sample period:

$$
r_{i, t}=\alpha_{i}+\sum_{l=-2}^{2}\left(\beta_{1, i, t+l} r_{m, t+l}+\beta_{2, i, t+l}\left(r_{U S, t+l}+e_{U S, m, t+l}\right)\right)+\varepsilon_{i, t}
$$

The explained variable, $r_{i, t}$, is the total return of firm $i$ 's stock in week $t$ in the local currency. The explanatory variables are $r_{m, t+l}$, the stock market return of economy $m$ where $i$ 's stock trades, in local currency, $r_{U S, t+l}$, the US stock market return (in US dollars), and $e_{U S, m(i), t+l}$, is the return from buying US dollar at the beginning of the week and selling at the end of the week in $m$ 's domestic currency. Including leads and lags, $l$, of $-2,-1,0,1$ and 2 weeks for the explanatory variables accounts for differences in time zones, illiquidity, and nonsynchronous trading. The residual, $\varepsilon_{i, t}$, is the firm-specific shock of stock $i$ in week $t$. We focus on how shocks to idiosyncratic component of stock returns, the $\varepsilon_{i, t}$, react to idiosyncratic shocks to commodity prices. 


\subsection{Idiosyncratic Commodity Shocks}

We construct economy-specific idiosyncratic commodity price shocks by considering how different commodities' prices can affect different economies' fundamentals differently. For example, an oil price increase might have a more widespread impact across all sectors in a heavily oil export dependent economy, such as Norway, than a more diversified economy such as Germany.

Datastream provides daily price indexes for major commodities, whose prices are globally determined, starting in $1993 .{ }^{6}$ Table 2 lists these and their Datastream identifiers. Following Gorton and Rouwenhorst (2004), commodity returns are changes in spot prices. Economy-level commodity shocks are the residuals from separate regressions of the form [2] for each commodity economy pair:

$$
r_{c, m, t}=\alpha_{c}+\sum_{l=-2}^{2}\left(\beta_{1, c, t+l} r_{m, t+l}+\beta_{2, c, t+l}\left(r_{U S, t+l}+e_{U S, m, t+l}\right)\right)+\varepsilon_{c, m, t}
$$

The explained variable $r_{c, m, t}$ is commodity $c$ 's weekly (Wednesday to Wednesday) return in economy $m$ 's local currency at time $t$. The explanatory variables are as in [1]. The idiosyncratic shock to commodity $c$ 's price change in economy $m$ in week $t$ is the residual, $\varepsilon_{c, m, t}$.

\subsection{Identifying Industry-Commodity Matches}

The tests below require identifying industries that are sensitive to shocks to the price of each commodity. In-sample estimation of these sensitivities is problematic because our hypothesis is that group affiliation may dampen the observable effects of commodity shocks on share prices.

\footnotetext{
${ }^{6}$ Commodities, such as natural gas, whose pricing is subject to segmented markets problems, are excluded from the sample.
} 
Three alternative methods of matching industries to commodities are employed to circumvent this problem.

\subsubsection{Statistical Method}

This method reapplies the methodology of Rajan and Zingales (1998), who use US data to estimate external finance-dependence across industries in that economy and infer that the same industries are apt to require external financing elsewhere. We likewise use US data, which is left out-of-sample in tests using this methodology, to estimate commodity price-dependence across industries in the US and infer that the same industries are commodity price-sensitive in other economies too.

Following Rajan and Zingales (1998) in using US data to identify industry-commodity has several advantages. First, because business groups are relatively rare in the US (La Porta et al., 1999; Villalonga and Amit, 2009; Masulis et al., 2011), group affiliation is relatively less likely to damp the observable effects of commodity shocks on share prices there. US industries' commodity price sensitivities are thus a useful out-of-sample benchmark, against which to gauge how business group affiliation might dampen commodity price-sensitivity in economies where business groups are important. Second, US stock prices appear to incorporate more firm-specific information (broadly defined) than do stocks in most other economies (Bartram, Brown and Stulz, 2012). Finally, because the US has, on average, more listed firms per industry, US data provide more precise point estimates in the exercise below.

Firm-level US data are from Compustat and CRSP. Using FF-30 industries ensures a large number of firms in each industry to estimate industry sensitivity to commodities. Firms that hedge commodity risk may exhibit a lower sensitivity to commodity shocks; however, smaller 
US firms are less likely to hedge (Nance, Smith, and Smithson, 1993; Geczy, Minton, and Schrand, 1997; Carter, Rogers, and Simkins, 2006; Rampini, Sufi, and Viswanathan, 2014). We therefore use the smallest quartile (by market capitalization) of US firms in each industry at the beginning of each month to match industries to commodities.

Each US industry is matched to one commodity by assessing how sensitive firm-specific return shocks in an industry are to idiosyncratic shocks in the prices of different commodities. This is accomplished by estimating the following three sets of regressions:

$$
\begin{array}{cc}
\forall \text { firms } i, & r_{i, t}=\alpha_{i}+\sum_{l=-2}^{2}\left(\beta_{i, t+l} r_{U S, t+l}\right)+\varepsilon_{i, t}, \\
\forall \text { commodities } c, & r_{c, U S, t}=\alpha_{c}+\sum_{l=-2}^{2}\left(\beta_{c, t+l} r_{U S, t+l}\right)+\varepsilon_{c, U S, t}, \\
\forall \text { industries } j, & \varepsilon_{i(j), t}=\alpha_{j}+\sum_{c=1}^{19}\left(\beta_{c, j} \varepsilon_{c, U S, t}\right)+\tau_{i, t} .
\end{array}
$$

Regressions [3a] and [3b] adapt [1] and [2] to US firms. Regression [3c], which runs pooled regressions for each industry $j$, explains residuals $\varepsilon_{i, t}$ from [3a] with contemporaneous residuals $\varepsilon_{c(U S), t}$ from [3b]. That is, [3c] explains variation in the firm-specific shocks in week $t$ stock return of small US firms $i$ in industry $j$ with variation in the US economy-specific idiosyncratic components of the return to holding commodity $c$ that week. The $\tau_{i, t}$ are regression residuals in $[3 \mathrm{c}]$. A tighter link between commodity $c$ and industry $j$ is inferred from a more statistically significant loading $\beta_{c, j}$ in the regression [3c] for that industry.

We require a minimum threshold of three for the absolute value of the $t$-statistic of the loading $\beta_{c, j}$ and then select the commodity-industry pair with the highest absolute $t$-statistic 
among these as a potential match. We then run a univariate second pass regression analogous to [3c] - namely, $\varepsilon_{i, t}=\beta_{c, j} \varepsilon_{c(U S), t}+\tau_{i, t}$ - for the potential match. We declare a match between industry $j$ and commodity $c$ only if the commodity's coefficient has the same sign as in the firstpass regression and the $t$-statistic in this second pass regression also exceeds three in absolute value. This extra step is done to cull false matches due to multicollinearity (no false matches are identified).

The major advantage of the statistical method is that it gauges an industry's sensitivity to commodity prices through all possible channels. For example, a shock to oil prices might affect the auto industry by affecting input prices (supply shock) or consumer preferences as to the type of car (demand shock). The commodity matches identified with this procedure could proxy for the prices of goods that affect an industry, but for which no global commodity market exists (Anderson and Danthine, 1981), other fundamental shocks that affect an industry, substitutes for industry's main product, or other such factors. In all such cases, the industry-commodity match is valid for our analysis as long as the shock to the matched commodity is a good proxy for the unobserved fundamental shock to the matched industry.

The major disadvantages of statistical matching are that type one and type two errors inevitably arise, missing genuine matches and declaring spurious matches. Spurious or missed matches are likely to induce attenuation bias in the tests that follow. We therefore test whether industry commodity matches are valid out-of-sample in section 3 below.

Columns 1-3 in Table 2A list the industry-commodity matches detected using the "statistical" method. Some matches are intuitive, such as that between the "Precious Metals, Non-Metallic, and Industrial Metal Mining" industry and "Gold" and that between "Petroleum and Natural Gas" industry and "Crude Oil". Others link seemingly unrelated industries and 
commodities, such as "Fabricated Products and Machinery", matched to "Feeder Cattle". Closer investigation provides economic intuition for some of these. For example, farm equipment is included in the "Fabricated Products and Machinery" industry. Regardless, validating matches intuitively is subject to ex-post justification bias. We therefore take the matches as determined by the data.

We supplement tests using this approach with tests using matches based on a constrained statistical matching method and on Bureau of Economic Analysis (BEA) input-output (I-O) tables that list industries direct dependence on commodities. These alternative methods are discussed below.

\subsubsection{Constrained Statistical Method}

The method above generates statistically highly significant matches between some industries and commodities that may not be directly related. If these commodities capture genuine supply and demand, cross-industry, or latent factor effects, the method is useful. If these matches are false positives, tests using them suffer from attenuation bias.

The modified statistical method is designed to mitigate any such attenuation bias. This method uses the same algorithm as the statistical matching method, but adds the requirement that the commodity and industry be directly related. This retains the matches between "Petroleum and Natural Gas" and "Crude Oil", "Precious Metals" and "Gold", but drops several matches with "Feeder Cattle" and adds matches at finer (4 digit SIC) industry-levels between industries and commodities they directly produce or consume. We verify that, in the univariate second pass regression analogous to [3c], the $t$-statistic of the loading $\beta_{c, j}$ on commodity shocks exceeds three in absolute value for the additional industry-commodity matches introduced in this way. 
This adds matches between "Roasted Coffee" and "Coffee", "Meat Products" and "Feeder Cattle", "Lumber and Wood Products" and "Lumber" etc. Table 2-A Columns 4-6 list industrycommodity matches determined by this method.

The constrained statistical matching method potentially mitigates concerns about noisedriven matches and mismatches; but reduces the sample size by $74 \%$ because many fewer firms end up in industries matched to a commodity. This potentially gives rise to issues related to power in regressions. Therefore, we view this method as a robustness test.

\subsubsection{BEA Method}

An alternative and qualitatively different approach uses Bureau of Economic Analysis (BEA) input-output (I-O) tables. These list every industry's use of inputs produced by every other industry for approximately 56,000 industry pairs in the US. This matching method is not statistical-based, and thus avoids noise-driven matches and mismatches. However, it does not capture all possible channels through which commodity price shocks might affect an industry. For example, an increase in oil prices might boost the profits of coal mines, which produce a substitute for oil but do not use much oil as input.

The BEA matching method proceeds as follows: First, a set of basic commodity-linked industries is determined by identifying industries that produce each given commodity or use it as their predominant input. For example, "Cotton Farming" is linked to the commodity "Cotton", "Cattle Ranching and Farming" to "Feeder Cattle", "Petroleum Refineries" to "Crude Oil", and so on. We declare these "base" industries matched to that commodity and report them in Table 2B.

We then identify industries that depend on a commodity by summing each industry's 
inputs from the base industries that are already linked to the commodity. If at least $10 \%$ of an industry's inputs are from industries already linked to the commodity, we match that industry to the same commodity. For example, the base industries matched to "Crude Oil" provide $22 \%$ of the inputs of "Asphalt shingle and coating materials manufacturing", so we also match that industry to "Crude Oil." We repeat this matching process for two additional rounds, increasing the threshold for declaring a match to $20 \%$ in the second and $30 \%$ in third round because the number of industries matched to each commodity increases prior to each round. ${ }^{7}$ Table $2 \mathrm{~B}$ lists the 86 matches of (6 digit I-O classification) industries to commodities. ${ }^{8}$

\section{The Incorporation of Idiosyncratic Commodity Shocks into Stock Prices}

Regression [4] tests whether or not group affiliated firms' stock returns incorporate idiosyncratic information differently vis-à-vis unaffiliated firms. Following Jin and Myers (2005) we employ a variant of Fama-MacBeth estimation, which Petersen (2009) finds appropriate in panel regressions explaining abnormal returns. The regressions explain weekly shocks to firm-specific stock returns with idiosyncratic components of weekly shocks to the prices of matched commodities, calculated separately for each economy thus:

$$
\varepsilon_{i, t}=b_{1} \varepsilon_{c(j), m, t} \operatorname{sgn}\left(\beta_{c, j}\right)+b_{2} G_{i, t}+b_{3} G_{i, t} \varepsilon_{c(j), m, t} \operatorname{sgn}\left(\beta_{c, j}\right)+\sum_{v=4}^{N} b_{v} X_{i, t}+\delta_{j, m}+u_{i, t}
$$

The explained variable $\varepsilon_{i, t}$ is the firm-specific shock to the return of stock $i$ in week $t$ from [1].

\footnotetext{
${ }^{7}$ Alternative thresholds and additional rounds of matching generate similar results (unreported).We stop at the third round because a fourth adds only 2 additional matches.

${ }^{8} \mathrm{~A}$ concordance table provided by the BEA matches its I-O industry classification system with the NAICS industry classification and a second concordance table provided by the US Census Department links NAICS industries to the SIC classification system available in Datastream.
} 
The first explanatory variable, $\varepsilon_{c(j), m, t}$ is the idiosyncratic commodity shock $\varepsilon_{c, m, t}$ to country $m$ from equation [2] that is matched to the firm $i$ 's industry $j$. Multiplying the idiosyncratic component of commodity shock by $\operatorname{sgn}\left(\beta_{c, j}\right)$, which is one or minus one as $\beta_{c, j}$ in [3c] is positive or negative, respectively, sgn ensures that expected sign of $b_{1}$ is positive regardless of whether shocks to the price of commodity $c$ affect industry $j$ positively or negatively ${ }^{9}$. If firm $i$ 's industry, $j$, is not matched with any commodity $c$ the firm is dropped from the sample. The second explanatory variable is an indicator variable, denoted $G_{i, t}$, set to one if firm $i$ is a group affiliate at time $t$ and to zero otherwise.

In some specifications, we include firm-specific control variables, $X_{i, t}$ and industryeconomy fixed effects, denoted $\delta_{j, m}$, based on 30 Fama-French industries. Industry-economy fixed-effects subsume all latent factors with variation at the industry, economy, or industryeconomy levels. Moreover, the estimates in the tables are the means of week-by-week FamaMacBeth regressions, so the coefficients of the industry-economy fixed effects take different values each week, effectively leaving the regressions subsuming all time-varying industry, economy, and industry-economy level latent factors as well. In this context, Fama-MacBeth estimation also has the advantage of mitigating potential bias due to cross-sectional correlation in the firm-specific stock returns. The dependent variables are estimated idiosyncratic returns and so ought not to be autocorrelated, but to err on the size of underestimating significance levels, we allow for any potential autocorrelation in the firm-specific stock returns by assessing the significance of the means of the coefficients in [4] using Newey-West t-statistics, adjusted for 4week lags. 9 The sign of $\beta_{c, j}$ is similarly calculated using the regression specification [3c] for the BEA matched industry-
commodity pairs. 
The coefficient $b_{1}$ can be estimated if industry-economy fixed-effects are not introduced. A positive and significant coefficient for $b_{1}$ implies that, on average, commodities are correctly matched to industries. The coefficient of interest in [4] is $b_{3}$, that of the sign-adjusted interaction of the commodity shock measure $\varepsilon_{c(j), m, t}$ with the group affiliation indicator, $G_{i t}$. A negative and significant $b_{3}$ implies that group-affiliated firms exhibit a muted response to economy-specific commodity shocks as compared to unaffiliated firms.

Table 3 summarizes the main regression results. Regressions 3.1 and 3.2 use the variant of $\varepsilon_{c(j), m, t}$ calculated in [2] and matched to industries using the statistical method. Regressions 3.3 and 3.4 use the variant of $\varepsilon_{c(j), m, t}$ matched to industries using the constrained statistical method and regressions 3.5 and 3.6 use the variant of $\varepsilon_{c(j), m, t}$ matched to industries using the BEA matching method. Regressions 3.2, 3.4 and 3.6 include industry-economy fixed effects.

In regressions $3.1,3.3$ and 3.5 , the coefficient $b_{1}$ on the commodity shock measure is positive and statistically significant. This affirms that, on average, the industry-commodity matching procedure successfully identifies commodity shocks relevant to the firm-specific shocks to the returns of firms in those industries even out of sample. The coefficient $b_{1}$ in 3.1 links a one-percentage point idiosyncratic shock to commodity prices to a five basis point idiosyncratic shock to the stock prices of unaffiliated firms. The coefficient of the group affiliation indicator, $b_{2}$, is positive and significant in most regressions, implying that group affiliated firms have higher average idiosyncratic returns than unaffiliated firms have.

The key coefficient of interest is $b_{3}$, on the interaction of the commodity shock measure with the group affiliation indicator. This is negative and statistically significant in all specifications. This indicates a muted incorporation of commodity shocks into the idiosyncratic stock returns of group affiliated firms on average. Specifically, the interaction coefficient in 3.1 
links a one-percentage point shock to commodity prices to a three $(5.82-2.46=3.36)$ basis point shock to the firm-specific stock returns of group affiliated firms. This is about $40 \%$ less than the shock to unaffiliated firms' share prices and the difference between the two is highly statistically significant across all specifications. The regressions in Table 3 demonstrate a statistically and economically significant damping of the impact of idiosyncratic commodity price shocks on the idiosyncratic return of group affiliated firms relative to unaffiliated firms.

\section{Identification of Group Affiliation as the Culprit}

The results above show group-affiliated firms' stocks to be less responsive to a given economyspecific commodity shock than are unaffiliated peer firms in the same economy, industry and time. The primary vulnerability of the findings in Table 3 that remains is that group affiliated and unaffiliated firms might differ along other firm-level dimensions, some perhaps unobservable given data constraints. This section presents tests designed to mitigate these concerns.

\subsection{Mitigating Omitted Variables}

Table 1 Panel B shows group affiliated and unaffiliated firms differing from each other in diversification, leverage, hedging activity, size and R\&D activity. We therefore next include these control variables to mitigate concerns that group affiliation might be proxying for these other differences in firm characteristics.

A firm diversified across industries may exhibit a muted response to a commodity shock that affects only some of its industry segments. We also control for each firm's leverage. The stock prices of more leveraged firms are plausibly more sensitive to shocks. Group affiliated 
firms might hedge commodity risk more aggressively to shield the wealth of their controlling block holders (Tufano, 1996). We proxy for hedging activity in two alternative ways. One is a hedging indicator set to 1 if Datastream reports that the firm has financial accounts related to hedging or derivative usage as described in detail above. The second is firm size, reflecting prior findings showing larger firms to employ more extensive hedging strategies (Nance, Smith, and Smithson, 1993; Geczy, Minton, and Schrand, 1997; Carter, Rogers, and Simkins, 2006; Rampini, Sufi, and Viswanathan, 2014). The log of market capitalization or log of total assets proxies for firm size. We also control for each firm's R\&D spending each year. R\&D intensive firms' valuations are thought to depend more on future growth opportunities than on current conditions (and shocks that primarily affect current cash flows). All variables are measured annually at the prior fiscal year-end.

Table 4 summarizes these regressions, all of which expand regression 3.2 in Table 3 by including diversification, leverage, R\&D activity, total assets or market capitalization and their interactions with the industry-economy-specific commodity shock. Industries and commodities are matched using the statistical matching method. Regressions 4.1-4.6 incorporate the new control variables and matching interactions one pair at a time; regression 4.7 includes them all. No interaction is statistically significant in 4.1-4.6; however some interactions are significant in 4.7. More importantly, the interaction between the group affiliation indicator and the commodity shock measure remains uniformly negative and statistically significant. This suggests that omitting these firm-level characteristics in the previous analyses cannot explain group affiliated firms' muted stock price responses to commodity shocks.

Clearly, the tests in this section cannot mitigate all potential concerns about sources of confounding variation. In particular, the conclusions in this section are subject to the caveat that 
group-affiliated and unaffiliated firms might differ along other dimensions, including dimensions unobservable to us due to data limitations.

\subsection{Changes in Group Affiliation: Difference-in-Difference Tests}

An alternative identification strategy is based on a difference-in-differences setting, where changes in group affiliation act as the "treatment". These difference-in-differences tests explore differences in how sensitive the firm-specific shocks (in commodity-sensitive industries) to relevant commodity price shocks before versus after the firms' status as group affiliated versus unaffiliated changes (the "treatment" group). These are compared to contemporaneous differences in the firm-specific shocks of firms whose group affiliation status does not change (the "control" group). Identification comes from firms whose group affiliation status does not change serving as a counterfactual for how "treated" firms' firm-specific stock returns would have responded to the commodity shocks had their affiliation status not changed. As in all difference-in-difference tests, the identification assumptions are that omitted firm-level characteristics do not significantly change around the treatment and that the change in group affiliation is exogenous. Relaxing these identification assumptions is explored in the next subsection.

The treatment group consists of firms that are unaffiliated in one year and group affiliated in the following year (positive treatment firms) or affiliated in one year an unaffiliated in the following (negative treatment). These tests require that the firms we designate as "treated" genuinely do change affiliation status. Recall that group affiliation is inferred from a firm having another firm as its controlling shareholder, controlling another firm, or being controlled by a controlling shareholder who controls another firm. We use a $20 \%$ minimum threshold for 
designating any given equity block sufficient to exercise control, and thus to make a firm a group affiliate. We do not want blocks that either meet or fail to meet the threshold briefly or by small margins to count as changes in group affiliation status. The treatment group therefore is restricted to firms whose group affiliate status changes because the control block(s) relevant to its status change(s) by at least five percentage points and whose status does not change during the prior or subsequent two-year periods. This effectively excludes, from the treatment group, firms attached to their groups due to stakes varying around the threshold because such fluctuations might reflect seasoned equity issues, share buybacks, stock dividends, or share creation associated with stock options, rather than genuine changes in group affiliation status. The data excludes firms that either list or delist within the same windows because differences in betas cannot be calculated for these firms.

We use propensity scores matching to match each treatment firm with a control firm, whose group affiliation status does not change, within the same industry, economy, and year using the nearest neighbor matching (Abadie et al., 2004) by firm size, leverage, R\&D over assets and commodity beta in the prior year (estimated as explained below). If no match is available from the same country-industry-year, we default to a global match from the same industry-year. We require differences in propensity scores to be within the 0.05 range. Positively and negatively treated firms are matched separately. Matching is done with replacement to preclude the order of the observations from affecting the results.

Commodity betas for each treatment firm and control firm are estimated with respect to the industry-matched commodity return for each year. This entails estimating a variant of regression equation [3c] separately for each firm. In these, the explained variable is firm-level idiosyncratic return shocks and the explanatory variable is the idiosyncratic shock to the 
commodity matched with the firm's industry. Firms with fewer than 24 weeks of data are dropped from the sample, and betas are symmetrically winsorized at the five percent level to mitigate the impact of outliers. First differences in the commodity betas of each firm are then calculated. The tests then focus on the difference between treatment and control firms in these differences in commodity beta.

These difference-in-difference tests, summarized in Table 5, align with the findings in the previous tables. Group affiliation mitigates the sensitivity firm-specific stock returns to industryspecific commodity price shocks. The commodity beta of unaffiliated firms that become affiliated (positively treated firms) on average falls significantly, by -3.96 (p-value $=0.00$ ); while the commodity beta of their nearest neighbor firms, whose group affiliation does not change, remains constant on average. The commodity beta of affiliated firms that become unaffiliated (negatively treated firms) on average rises significantly, by 2.88 (p-value $=0.07$ ); while the average beta of their nearest neighbor firms displays a statistically insignificant decline of -0.45 . The difference-in-difference point estimate for negatively treated firms is a statistically significant $3.33(\mathrm{p}$-value $=0.08)$. Because the first differences of treated firms are always in the predicted direction and statistically significant, while those of the nearest neighbor firms are statistically insignificant, the results are driven by the changes in treated firms rather than changes in the control group.

Pooling positively and negatively treated firms (after multiplying negatively treated firms' differences in commodity beta by minus one) generates a highly statistically significant difference-in-difference estimate of about $-3.57(\mathrm{p}$-value $=0.00)$.

Thus, shocks to the firm-specific returns of group-affiliated firms that become unaffiliated are immediately more sensitive to commodity price shocks and shocks to the firm- 
specific returns of unaffiliated firms that become affiliated are immediately less sensitive to commodity price shocks.

\subsection{Placebo Tests Exploiting Failed M\&A Transactions}

Identification in the previous section relies on the assumption that firms become affiliated or unaffiliated for exogenous reasons. If changes in group affiliation status are endogenous, a sample selection bias problem arises. The results would be also consistent with, for example, groups taking on firms that are expected to become less sensitive to commodity shocks and divesting firms expected to become more sensitive to commodity shocks. One approach to mitigating such concerns follows Seru (2014) in comparing successful control block acquisition attempts to (unsuccessful) acquisition attempts that failed for plausibly exogenous reasons. If control block targets are selected in anticipation of changes in their sensitivity to commodity risk, rather than group affiliation being the cause of those changes, we would observe changes in the sensitivity to commodity risk also among targets of unsuccessful acquisition attempts.

Control block acquisition attempts recorded in the Thomson One database are merged with our ownership data. We require that the bidder seek to own at least $20 \%$ of the target's shares after the transaction and that the target be classified as unaffiliated in the year prior to the bid. Instances of firms purchasing their own shares are dropped.

The treatment group consists of target firms that are (1) unaffiliated prior to the acquisition announcement; (2) become group affiliated as a result of a successful acquisition; and (3) continue to be publicly traded so their commodity betas can be estimated after the acquisition. The latter requirement is especially important in this context because acquisitions in most economies entail acquiring a sufficient block of stock to exercise effective control, and are 
not bids for all of the target firm's shares as is generally the case in the US.

The control group consists of targets that are (1) unaffiliated prior to the acquisition announcement; (2) remain unaffiliated because the acquisition attempt failed due to a plausibly exogenous reason; and (3) continue to be publicly traded after the failed acquisition attempt. Acquisition bids that failed due to "plausibly exogenous reasons" consist of acquisition attempts, as reported in Thomson One, that failed because of (1) intervention by regulatory bodies (Savor and Lu, 2009; Seru, 2014; Faccio and Hsu, 2017); (2) court decisions (Seru, 2014; Faccio and Hsu, 2017); (3) employee opposition; or (4) unexpected adverse market-wide conditions (e.g., the 2008 financial crisis, the 1997 Asian financial crisis, etc., as in Seru, 2014). Acquisition bids that failed due to fluctuations in commodity prices are excluded, as are takeovers that failed because a rival bidder acquired a control block. The latter are excluded because the rival's takeover is included in the treatment group. The reasons behind the failure of each given transaction are determined based on the deal description in Thomson One, Capital IQ, and newspapers articles in Factiva and Lexis-Nexis.

In these tests, identification follows from the targets of unsuccessful acquisition attempts (placebo treatment firms) serving as counterfactuals for how successfully acquired targets' (actual treatment firms) sensitivities to commodity shocks would have changed had they not been acquired.

As in the previous section, we use propensity score matching to match targets of successful acquisitions with targets of unsuccessful acquisitions within the same economy, industry and year (if possible) using the nearest neighbor matching (Abadie et al., 2004) using total assets, leverage, $R \& D$ expenses as a fraction of total assets and commodity beta in the prior year as covariates. If no match is available from the same country, we default to a global match 
from the same industry-year. As before, the matching is done with replacement.

Betas with respect to industry-matched commodities are estimated for treatment and control firms over the 52 weeks before and 52 weeks after the takeover announcement date, excluding the announcement week. Firms with fewer than 24 weeks of observations are dropped and betas are winsorized at the five percent level.

As Table 6 shows, the results of the tests based on takeover attempts that failed for plausibly exogenous reasons do align with those in the previous tables. Firm-specific stock returns become significantly less sensitive to commodity shocks after a firm becomes affiliated with a business group following a successful takeover, in contrast to control firms that remain unaffiliated after a takeover attempt that failed for plausibly exogenous reasons. These tests mitigate the concern that our previous results might be due to self-selection.

\subsection{Within-Group Risk Sharing}

If a commodity shock to a one group firm is diffused across the group, other firms in the group would appear sensitive to the shock. Tests for this "second-hand commodity shock sensitivity" must therefore focus on business groups containing one or more firms in industries sensitive to a given commodity and one or more firms in industries insensitive to that commodity. These tests are best illustrated by a simple example. Consider a business group of three firms: Firm $F_{1}$ in an industry sensitive to commodity $\mathrm{C}_{1}$; firm $\mathrm{F}_{2}$ in an industry sensitive to commodity $\mathrm{C}_{2}$; and firm $F_{3}$ in an industry insensitive to any commodities. One set of tests explores whether $F_{1}$ is sensitive to $C_{2}, F_{2}$ is sensitive to $C_{1}$, and $F_{3}$ is sensitive to both $C_{1}$ and $C_{2}$.

We employ a variant of the Fama-Macbeth regressions [4] of the form, 


$$
\varepsilon_{i, t}=b_{1} \varepsilon_{c(j), m, t} \operatorname{sgn}\left(\beta_{c, j}\right)+b_{2} \varepsilon_{\neg c(j), m, t} \operatorname{sgn}\left(\beta_{\neg c, j}\right)+u_{i, t} .
$$

As in [4], the explained variable $\varepsilon_{i, t}$ is the firm-specific shock to the return of stock $i$ in week $t$ from [1]. Unlike in [4], where the explanatory variable $\varepsilon_{c(j), m, t}$ was idiosyncratic shock to the price of commodity $c$ matched to $i$ 's industry $j$ in its economy $m$ in week $t$; in [5] the explanatory variable of interest, $\varepsilon_{\neg c(j), m, t}$, is shock to the price of a commodity $\neg c(j)$, which is not $c(j)$, but a different commodity matched to the industry of another firm in firm $i$ 's group. As in [4], $\operatorname{sgn}\left(\beta_{\neg c, j}\right)$ is one or minus one as $\beta_{\neg c, j}$ is positive or negative, respectively, and inverts the sign of the explanatory variable if the industry loads negatively on its matched commodity.

If there were no risk sharing across groups, shocks to the industries of a firm's fellow group affiliates would not affect its own shares and the regression coefficient $b_{2}$ in [5] would be zero. If group-level risk sharing or income shifting are important, $b_{2}$ would be significantly positive.

Table 7 summarizes Fama-MacBeth regressions of [5]. Regression 7.1 considers firm's reaction to all commodities that affect the industries of its fellow group firms but do not affect the firm's own industry. The coefficient of $b_{2}$ is statistically significant and its point estimate, 0.86 is about $25 \%$ of the main coefficient in regression 3.1 , which is 3.36 . These point estimates indicate that a second hand commodity shock, affecting the industry of one or more of a firm's fellow group affiliates, moves its stock by about $25 \%$ as much as does a commodity shock to the firm's own industry.

However, commodity shocks are on average positively correlated and even if a firms' industry does not match with the other group firms' commodity a positive coefficient may ensue 
as a result of this correlation. Regression 7.2 controls for the shocks to firms' own matched commodity. The coefficient of $b_{2}$ is now 0.7 and barely statistically significant at $10 \%$. Second hand commodity shocks would stand out more clearly if the shocks they echo are larger. To restrict our analysis to severe second hand commodity shocks, we sort commodity shocks by their absolute values for each economy and retain only the top quartile of these for each economy. Regression 7.3 repeats the test with this sample. The coefficient $b_{2}$ increases to 1.1 and becomes statistically significant at $2 \%$ level. More severe commodity shocks to a firm's fellow group affiliates thus tend to affect its own share price more. This indicates that grouplevel risk sharing intensifies in response to more intense commodity shocks to a group member firm.

Finally, a group affiliate not matched to a commodity might show a stock return response if its industry is somewhat sensitive to that commodity, but not sensitive enough to meet the tstatistic $>3$ matching threshold in regression [3c]. Such a high threshold makes sense for our other tests, where misattributing commodity sensitivity to an industry that is actually not commodity sensitive must be avoided. In these tests, we instead need to avoid falsely classifying a sector as commodity insensitive. To address this concern, we focus on firms in industries that do not statistically significantly load on any commodity shocks in regression [3c] by requiring the absolute value of t-statistics of beta to be less than 0.5 for the firms' industry and commodity to be included in the test in regression 7.1. Results are displayed in regression $7.4^{10}$. The coefficient on other group firm shock is 2.5 and is statistically significant with a p-value of 0.08 .

Overall, we find a statistically significant, albeit attenuated, effect in the idiosyncratic

\footnotetext{
${ }^{10}$ In this test the total number of observations is less than 40,000 , which corresponds to about 36 observation per week. We use monthly regressions, instead of weakly, to mitigate concerns related to running cross-sectional regressions with few observations. When we run Fama-Macbeth regressions at the weekly level, we obtain a coefficient of 6.2 that is statistically significant with p-value $=0.04$.
} 
stock returns of group firms to shocks to other firms within the same business group. This is consistent with shocks being spread across firms in the same group.

\section{Robustness Tests}

We run a number of robustness tests using the specification in regression 3.2 of Table 3 . If the coefficient of the interaction between group affiliation and idiosyncratic commodity shock measure is negative and significant at the $10 \%$ level, we say that the tests generate results that are qualitatively similar to those in table 3.

\subsection{Alternative Method of Matching Commodities with Industries}

An alternative to matching based on statistical significance considers economic significance as well. The statistical matching method assumes that a more statistically significant loading $\beta_{c, j}$ on commodity $c$ implies a tighter link between the commodity and industry $j$. A plausible variant of the statistical method infers a tighter link if the economic impact of a shock to a commodity price, defined as the standard deviation of shocks to that commodity multiplied by the point estimate $\beta_{c, j}$, is the tightest. This approach matches an industry to the commodity with the highest economic impact, assessed in this way, whose loading $\beta_{c, j}$ also (1) has a $t$-statistic exceeding three in absolute value and (2) retains the same sign in the second step single regressions as in the first step multivariate regression, as defined above in the description of the statistical matching method. While new matches emerge, most intuitive matches remain (the list of matches are available on request). For example, the "Petroleum and Natural Gas" industry remains matched with the commodity "Crude Oil" because that commodity has both the most statistically significant and most economically important loading for stock returns in that 
industry. Regression 8.1 of Table 8 , using matches determined by this method, generates results that are qualitatively similar to those in Table 3.

\subsection{Diversification through Share Ownership}

We have controlled for firms with sales diversified across industries. Similarly, firms that are at the top of the business groups pyramids could be diversified if the firms in which they hold stakes operate in different industries. As a result, firms at the top of pyramids could be less sensitive to commodity shocks. To mitigate this concern, we repeat our main test using only firms that are at the bottom of a pyramid. To do this, we drop group affiliates that control other firms in the sample. Regression 8.2 in Table 8 shows that our results continue to hold when we focus on firms that are at the bottom of the business group pyramid.

\subsection{Alternative Ways of Identifying Business Groups}

Our main tests in Table 3 use a 20\% threshold for designating a firm's largest shareholder as its controlling shareholder. Using a relatively high stake may under-identify group affiliated firms if smaller stakes suffice to lock in control if other equity is diffusely held and small shareholders do not vote at shareholder meetings. Erroneously classifying some group-affiliated firms as unaffiliated introduces attenuation bias in our tests. To explore the sensitivity of our tests to this concern, we construct an alternative version of the group affiliation indicator variable, Group $p_{i, t}$, reclassifying controlling shareholders as those with stakes exceeding $15 \%$ and then reassessing group as described in Section 2.1. Regression 8.3 in Table 8, shows that this change yield results 
qualitatively similar to those in Table $3 .^{11}$

\section{$5.4 \quad$ Alternative Samples}

Our results are not driven by a few economies or extreme observations. For example, regression 8.4 in Table 8, which is also based on the statistical matching, shows that dropping Japan and the UK (the US is again excluded), which have the largest number of observations, yields qualitatively similar results.

Qualitatively similar results are ensue after winsorizing firm-specific stock returns and economy-specific commodity returns at $1 \%$ (unreported).

We have roughly 20 years of ownership data in the sample; however, ownership data coverage becomes more comprehensive in the latter 10 years. Fama-MacBeth regressions give equal weights to every time period regardless of the number of observations. Dropping the initial 10 years of data and repeating our tests using only the 2003-2013 period yields results, summarized in regression 8.5 of Table 8 , that are qualitatively similar to those in Table 3 .

\subsection{Alternative Regression Specification}

We employ Fama-MacBeth estimation following Jin and Myers (2006) and Petersen's (2009) finding that this approach is appropriate in panel regressions explaining abnormal returns. An alternative is to run panel regressions where we control for country*industry*time fixed effects and double cluster at the country*industry and business-group level. Regression 8.6 in Table 8 shows that the coefficient of Idiosyncratic Commodity Return * Group Affiliated Firm is negative and statistically significant although the coefficient is -0.98 , which is slightly smaller

\footnotetext{
${ }^{11}$ The number of observations drops slightly when $15 \%$ threshold is used because the number of firms identified as controlled by governments, which are dropped from the sample, increases.
} 
than the corresponding coefficients estimated by Fama-MacBeth regressions.

\subsection{Alternative Asset Pricing Model}

Since our goal is to test whether idiosyncratic shocks are differently incorporated into the stocks prices of group affiliated firms versus non-affiliates, we focus on the relationship between idiosyncratic shocks to stock returns and idiosyncratic shocks to commodity prices with respect to the international version of CAPM developed by Jin and Myers (2006) precisely to provide such a variance decomposition. A priori we do not expect the Jin and Myers international CAPM to result in biased estimations of idiosyncratic shocks for group affiliated versus unaffiliated firms. Nonetheless, it is useful to test whether results are affected by the choice of the particular asset pricing model.

We use a global version of Fama and French (2015) 5 factor model, where we change specifications [1] and [2] to include local market returns and Fama-French global 5 factors on the right hand side in estimating idiosyncratic component of firm and commodity returns, respectively. Regression 8.7 in Table 8 shows that the coefficient of Idiosyncratic Commodity Return * Group Affiliated Firm is negative, slightly larger in magnitude than in regression 3.2 and highly statistically significant.

\section{Business Groups and R-squared around the World}

We interpret the tests above as evidence that business group affiliation damps firm-specific shocks associated with commodity price changes. If business group affiliation similarly buffers other firm-specific shocks, share prices in general might co-move more in economies where business groups are more important. Therefore, we explore whether firm and economy level 
stock price co-movement correlates with the incidence of business groups.

To do this, we define the co-movement of firm $i$ 's stock return with its market return in year $t$ to be

$\Upsilon_{i, t}=\log \left(\frac{R_{i, t}^{2}}{1-R_{i, t}^{2}}\right)$

where $R_{i, t}^{2}$ is the regression R-squared statistic of [1] run on weekly returns for each firm in each year. The logistic transformation [6], which follows Morck et al. (2000), generates a variable with a roughly normal distribution and that is more positive for stocks whose shares more closely track market returns and more negative for stocks whose prices move more idiosyncratically.

We then run regressions explaining $\Upsilon_{i, t}$ with firm-level group affiliation controlling for economy-level variables shown elsewhere to correlate with stock return co-movement: $\log$ GDP per capita (Morck, Yeung and Yu, 2000), property rights (Morck, Yeung and Yu, 2000) and accounting standards (Jin and Myers, 2006). ${ }^{12}$

Table 9 displays Fama-MacBeth regressions of $\Upsilon_{i, t}$ on these explanatory variables. We use Newey-West estimator with 10 years lag to adjust for persistence in country level variables. As in prior studies, log GDP per capita attracts a negative coefficient across all specifications and is uniformly significant. Property rights enters insignificantly if alongside other variables but is significant when included alone (not reported). These results accord with the prior literature.

The primary variable of interest, Group Affiliation, attracts a positive and significant coefficient in all specifications. Group-affiliated firms' stock returns have significantly higher comovement with their markets or, in other words, less idiosyncratic volatility as a fraction of

${ }^{12}$ GDP per capita is from World Bank WDI dataset. Property rights index data is from Heritage Organization website 2013 index of economic freedom. Accounting standards is from LaPorta et al. (1998). 
total volatility than do unaffiliated firms.

These findings suggest that more pervasive business group affiliation might be added to the list of economy characteristics associated with greater stock return co-movement. Figure 1 Panel C visually confirms this pattern, with economy level co-movement measure from Morck et al. (2013) on the vertical axis and the fraction of observations that are form group affiliates, from Table 1, on the horizontal axis. Stocks in countries with more group affiliated firm observations have statistically significantly $(\mathrm{p}=0.09)$ higher economy level stock return co-movement. The considerable scatter around the positive correlation line leave abundant room for other mechanisms and chains of causality.

These findings link the prior literature, surveyed in Morck et al. (2013), explaining more idiosyncratic stock return co-movement with less developed market institutions to the literature, surveyed by Khanna and Yafeh (2007), explaining business groups prevalence with less developed market institutions. And our difference-in-difference findings, especially those using failed control block bids, also affirm a direction of causation at the firm-level: business group affiliation damps idiosyncratic stock return volatility, which in return causes share price comovement. ${ }^{13}$ Firm-level data on business groups causing attenuated commodity shock-related firm-specific stock return volatility thus provides new economic intuition to explain, partially at least, economy-level patterns in stock return co-movement.

\section{Conclusions}

Business group member firms are less sensitive to commodity shocks than are otherwise similar

\footnotetext{
${ }^{13}$ Khanna and Thomas (2009) find interlocking boards, more than common controlling owners, in Chilean firms correlated with share price co-movement.
} 
unaffiliated firms at the same time and in the same economy and commodity-sensitive industry. Difference-in-difference tests are consistent with business group affiliation damping a firm's stock return sensitivity to commodity price shocks. Further tests show damped firm-specific volatility more generally in the stocks of business group affiliates and link cross-economy differences in overall stock return co-movement to differences in the prevalence of business groups.

Business groups, as a second best hierarchical allocation mechanism (Coase 1937) in response to inefficient financial and other markets (Morck et al. 2005; Khanna and Yafeh 2007), allocate capital internally within the group (Almeida and Wolfenzon, 2006b; Morck, Yavuz and Yeung 2011). Internal capital markets may also be used to maximize ultimate controlling shareholders' private benefits (Bertrand et al. 2002), for example, by siphoning off group member firms' firm-specific abnormal earnings (Jin and Myers 2006). The extent to which business group affiliates' share price responses to commodity price shocks are attenuated relative to unaffiliated firms' share price responses may be a useful empirical variable measuring the extent to which investors expect business groups to shift resources and risk across their affiliates. We welcome research using shock sensitivity to better discern how business groups are governed.

Where markets expect more extensive resource and risk shifting across group affiliates, their stock prices provide less information feedback to each individual firm's managers and capital providers (Bond et al. 2012). That is, by responding to market imperfections with more active hierarchical allocation, business groups may impair this important information transmission role of the stock market. 


\section{References}

Abadie, A., Drukker, D., Herr, J.L. and Imbens, G.W., 2004. Implementing matching estimators for average treatment effects in Stata. Stata Journal, 4, 290-311.

Almeida, H., Park, S.Y., Subrahmanyam, M.G. and Wolfenzon, D., 2011. The structure and formation of business groups: Evidence from Korean chaebols. Journal of Financial Economics, 99(2), pp.447-475.

Almeida, H. and Wolfenzon, D., 2006a. A theory of pyramidal ownership and family business groups. The Journal of Finance, 61(6), pp.2637-2680.

Almeida, H. and Wolfenzon, D., 2006b. Should business groups be dismantled? The equilibrium costs of efficient internal capital markets. Journal of Financial Economics, 79(1), pp.99144.Bae, K.H., J.K. Kang, and Kim, J.M., 2002. Tunneling or Value Added? Evidence from Mergers by Korean Business Groups. Journal of Finance, 57, 2695-2740.

Anderson, R.W. and Danthine, J.P., 1981. Cross hedging. Journal of Political Economy, 89(6), pp.1182-1196.

Baek, J.S., Kang, J.K., and Lee, I., 2006. Business groups and tunneling: Evidence from private securities offerings by Korean chaebols. Journal of Finance, 61, 2415-2449.

Bartram, S.M., Brown, G. and Stulz, R.M., 2012. Why are US stocks more volatile? Journal of Finance, 67(4), 1329-1370.

Bertrand, M., Mehta, P. and Mullainathan, S., 2002. Ferreting out tunneling: an application to Indian business groups. Quarterly Journal of Economics, 117(1), 121-148.

Betton, S., Eckbo, B.E. and Thorburn, K.S., 2009. Merger negotiations and the toehold puzzle. Journal of Financial Economics, 91(2), 158-178.

Bond, P., Edmans, A. and Goldstein, I., 2012. The real effects of financial markets. Annual Review Financial Economics, 4(1), pp.339-360.

Carter, D.A., Rogers, D.A., Simkins, B.J., 2006. Hedging and value in the US airline industry. Journal of Applied Corporate Finance, 18(4), 21-33.Chun, H., Kim, JW, and Morck, R, 2011. Varying heterogeneity among US firms: facts and implications, Review of Economics and Statistics, 93(3), 1034-1052.

Coase, R. H.1937. The nature of the firm. Economica 4(16), 386-405.

Durnev, A., Morck, R. and Yeung, B., 2004. Value-enhancing capital budgeting and firmspecific stock return variation. Journal of Finance, 59(1), 65-105.

Faccio, M. and Hsu, HC, 2017. Politically connected private equity and employment, Journal of Finance, 72(2), 539-573.

Faccio, M. and O'Brien, W., 2015. Business groups and internal markets for human capital. Working Paper, Krannert School of Management Purdue University.

Faccio, M., Lang, L., and Young, L., 2001. Dividends and expropriation, American Economic Review, 91(1), 54-78.

Faccio, M., Marchica, M.T. and Mura, R., 2011. Large shareholder diversification and corporate risk-taking. Review of Financial Studies, 24(11), 3601-3641.

Fama,E.F. and French K. R.,2015. A five-factor asset pricing model. Journal of Financial Economics, Volume 116, Issue 1, 2015, pp. 1-22

Fogel, K., 2006. Oligarchic family control, social economic outcomes, and the quality of government. Journal of International Business Studies, 37(5), pp.603-622.

Friedman, E., Johnson, S., and Mitton, T., 2003. Propping and tunneling. Journal of Comparative Economics, 31, 732-750. 
Geczy, C., Minton, B.A., Schrand, C., 1997. Why firms use currency derivatives. Journal of Finance, 52, 1323-1354.

Gilje, E., Gormley, T.A. and Levit, D., 2018. The rise of common ownership. Working paper.

Gopalan, R., Nanda, V. and Seru, A., 2007. Affiliated firms and financial support: Evidence from Indian business groups. Journal of Financial Economics, 86(3), 759-795.

Gorton, G. and Rouwenhorst, K.G., 2004. Facts and fantasies about commodity futures. National Bureau of Economic Research. No. w10595

Hoshi, T., Kashyap, A., and Scharfstein, D., 1990. The role of banks in reducing the costs of financial distress in Japan. Journal of Financial Economics, 27(1), 67-88.

Hoshi, T., Kashyap, A., and Scharfstein, D., 1991. Corporate structure, liquidity, and investment: Evidence from Japanese industrial groups. Quarterly Journal of Economics, 106(1), 3360.

Irvine, P.J. and Pontiff, J., 2009. Idiosyncratic return volatility, cash flows, and product market competition. Review of Financial Studies, 22(3), 1149-1177.

Jin, L. and Myers, S.C., 2006. $\mathrm{R}^{2}$ around the world: New theory and new tests. Journal of Financial Economics, 79(2), 257-292

Johnson, S., La Porta, R., Lopez-de-Silanes, F., and Shleifer, A., 2000. Tunneling. American Economic Review, 90, 22-27.

Khanna, T., and Thomas, C. 2009. Synchronicity and firm interlocks in an emerging market. Journal of Financial Economics, 92(2), 182-204.

Khanna, T., and Yafeh, Y., 2005. Business groups and risk sharing around the world. Journal of Business, 78(1), 301-340.

Khanna, T., and Yafeh, Y., 2007, Business Groups in Emerging Markets: Paragons or Parasites? Journal of Economic Literature, 45(2), 331-372.

Kim, JB, Yu, Z, and Zhang, H, 2016. Can media exposure improve stock price efficiency in China and why? China Journal of Accounting Research, 9(2), 83-114.

Kornai, J. 1986. The soft budget constraint. Kyklos, 39(1), 3-30.La Porta, R., Lopez-de-Silanes, F., and Shleifer, A., 1999. Corporate ownership around the world, Journal of Finance, 54(2): 471-518.

La Porta, R., Lopez-de-Silanes, F., Shleifer, A. and Vishny, R.W., 1998. Law and finance. Journal of Political Economy, 106(6), 1113-1155.

Masulis, R.W., Pham, P.K., and Zein, J., 2011. Family business groups around the world: financing advantages, control motivations and organizational choices. Review of Financial Studies, 24, 3556-3600.

Morck, R., 2005. How to eliminate pyramidal business groups: the double taxation of intercorporate dividends and other incisive uses of tax policy. Tax Policy and the Economy, 19, 135-179.Morck, R., and Nakamura, M., 1999. Banks and corporate control in Japan, Journal of Finance, 54(1) 319-340.

Morck, R, Wolfenzon, D, and Yeung, B, 2005. Corporate governance, economic entrenchment, and growth, Journal of Economic Literature, 43, 655-720.

Morck, R., Yavuz, M.D. and Yeung, B., 2011. Banking system control, capital allocation, and economy performance. Journal of Financial Economics, 100(2), pp.264-283.

Morck, R., Yeung, B., and Yu, W., 2000. The information content of stock markets: why do emerging markets have synchronous stock price movements? Journal of Financial Economics, 58, 215-260.

Morck, R., Yeung, B., and Yu, W., 2013. R ${ }^{2}$ and the economy, Annual Review of Financial 
Economics, 5, 143-166.

Nance, D.R., Smith, C.W., Jr., Smithson, C.W., 1993. On the determinants of corporate hedging. Journal of Finance, 48, 267-284.

Ouimet, P.P. 2012. What motivates minority acquisitions? The trade-offs between a partial equity stake and complete integration. Review of Financial Studies, 26(4), 1021-1047.

Perkins, S., Morck, R., and Yeung, B., 2014. Innocents abroad: the hazards of international joint ventures with pyramidal group firms. Global Strategy Journal, 4(4), 310-330.

Petersen, M. A., 2009. Estimating standard errors in finance panel data sets: Comparing approaches, Review of Financial Studies, 22, 435-480.

Rajan, R.G. and Zingales, L., 1998. Financial dependence and growth. American Economic Review, 88(3), 559-586.

Rampini, A.A., Sufi, A., and Viswanathan, S., 2014. Dynamic risk management. Journal of Financial Economics, 111: 271-296.

Rock, E.B., and Rubinfeld, D.L., 2017. Defusing the Antitrust Threat to Institutional Investor Involvement in Corporate Governance. New York University law School working paper.

Savor, PG, and Lu, Q, 2009. Do Stock Mergers Create Value for Acquirers? Journal of Finance, 64(3),1061-1097.

Schmalz, M.C., 2018. Common-ownership concentration and corporate conduct. Annual Review of Financial Economics, 10(1), 413-448.

Seru, A., 2014. Firm boundaries matter: Evidence from conglomerates and R\&D activity. Journal of Financial Economics, 111, 381-405.

Stulz, R.M., 2005. The limits of financial globalization. The Journal of Finance, 60(4), pp.15951638.

Tobin, J. 1984. On the Efficiency of the Financial System. Lloyds Bank Review 153(7)1-15.

Tufano, P., 1996. Who manages risk? An empirical examination of risk management practices in the gold mining industry. Journal of Finance, 51, 1097-1137.

Veldkamp, L.L., 2006. Information markets and the comovement of asset prices. Review of Economic Studies, 73(3), 823-845.

Villalonga, B., and Amit, R. 2009. How are US family firms controlled? Review of Financial Studies, 22(8), 3047-3091.

Wurgler, J., 2000. Financial markets and the allocation of capital. Journal of Financial Economics, 58(1), 187-214. 


\section{Table 1. Group Affiliated Firms}

The Panel A tabulates the count of firm-year observations in our final ownership sample during 1993-2013. Panel B reports mean characteristics of group affiliated and unaffiliated firms averaged across all available firm-year observations. We classify firms as group affiliated if they satisfy one of the following criteria: (1) The controlling shareholder is a corporation (with the exclusion of investment funds); (2) the controlling shareholder is an individual who controls at least one other firm in our sample; or (3) the firm itself is the controlling shareholder of at least one other firm in our sample. Firms that do not fit the above classification are classified as unaffiliated firms. State owned enterprises are excluded from the sample. Market size and total assets are in million USD.

Panel A: Incidences and Fractions of Group Affiliated Firm-Year Observations, by Economy

\begin{tabular}{|c|c|c|c|c|}
\hline Economy Name & $\begin{array}{c}\text { Unaffiliated Firm- } \\
\text { Year }\end{array}$ & $\begin{array}{l}\text { Group Affiliated } \\
\text { Firm-Year }\end{array}$ & Total & $\begin{array}{l}\text { Fraction of Group } \\
\text { Affiliated Obs. }\end{array}$ \\
\hline Australia & 14,847 & 4,292 & 19,139 & 0.22 \\
\hline Austria & 533 & 606 & 1,139 & 0.53 \\
\hline Belgium & 1,115 & 1,206 & 2,321 & 0.52 \\
\hline Brazil & 2,069 & 1,544 & 3,613 & 0.43 \\
\hline Canada & 19,601 & 3,687 & 23,288 & 0.16 \\
\hline Chile & 735 & 1,713 & 2,448 & 0.70 \\
\hline China & 6,661 & 7,519 & 14,180 & 0.53 \\
\hline Croatia & 280 & 339 & 619 & 0.55 \\
\hline Denmark & 2,330 & 513 & 2,843 & 0.18 \\
\hline Egypt & 508 & 189 & 697 & 0.27 \\
\hline Finland & 1,358 & 545 & 1,903 & 0.29 \\
\hline France & 7,674 & 4,718 & 12,392 & 0.38 \\
\hline Germany & 6,718 & 5,290 & 12,008 & 0.44 \\
\hline Greece & 1,893 & 464 & 2,357 & 0.20 \\
\hline Hong Kong & 5,493 & 6,817 & 12,310 & 0.55 \\
\hline India & 9,751 & 4,730 & 14,481 & 0.33 \\
\hline Indonesia & 2,252 & 1,284 & 3,536 & 0.36 \\
\hline Ireland & 866 & 245 & 1,111 & 0.22 \\
\hline Israel & 2,427 & 1,467 & 3,894 & 0.38 \\
\hline Italy & 1,468 & 1,871 & 3,339 & 0.56 \\
\hline Japan & 36,392 & 16,110 & 52,502 & 0.31 \\
\hline Jordan & 700 & 294 & 994 & 0.30 \\
\hline Kuwait & 518 & 362 & 880 & 0.41 \\
\hline Malaysia & 6,251 & 4,770 & 11,021 & 0.43 \\
\hline Mexico & 922 & 346 & 1,268 & 0.27 \\
\hline Netherlands & 1,947 & 729 & 2,676 & 0.27 \\
\hline New Zealand & 910 & 385 & 1,295 & 0.30 \\
\hline Norway & 1,647 & 1,086 & 2,733 & 0.40 \\
\hline Peru & 424 & 526 & 950 & 0.55 \\
\hline Philippines & 897 & 883 & 1,780 & 0.50 \\
\hline Poland & 1,612 & 925 & 2,537 & 0.36 \\
\hline Russian Federation & 1,091 & 905 & 1,996 & 0.45 \\
\hline Singapore & 3,965 & 4,035 & 8,000 & 0.50 \\
\hline South Africa & 2,804 & 2,062 & 4,866 & 0.42 \\
\hline South Korea & 9,026 & 4,117 & 13,143 & 0.31 \\
\hline Spain & 1,361 & 1,256 & 2,617 & 0.48 \\
\hline Sweden & 3,252 & 1,186 & 4,438 & 0.27 \\
\hline Switzerland & 2,475 & 1,322 & 3,797 & 0.35 \\
\hline Taiwan & 9,549 & 834 & 10,383 & 0.08 \\
\hline Thailand & 2,824 & 1,284 & 4,108 & 0.31 \\
\hline Turkey & 1,385 & 951 & 2,336 & 0.41 \\
\hline United Kingdom & 29,987 & 5,203 & 35,190 & 0.15 \\
\hline United States & 73,582 & 9,476 & 83,058 & 0.11 \\
\hline Total & 282,100 & 108,086 & 390,186 & 0.28 \\
\hline
\end{tabular}


Panel B: Mean Characteristics of Group Affiliated and Unaffiliated Firm-Year Observations

\begin{tabular}{|c|c|c|c|c|}
\hline \multirow[b]{2}{*}{ Firm Characteristic } & \multicolumn{2}{|c|}{ All Economies } & \multicolumn{2}{|c|}{ All Economies Except US } \\
\hline & Group Affiliated & Unaffiliated & $\begin{array}{c}\text { Group } \\
\text { Affiliated }\end{array}$ & Unaffiliated \\
\hline Diversification & -0.77 & -0.80 & -0.75 & -0.78 \\
\hline Leverage & 0.23 & 0.21 & 0.23 & 0.21 \\
\hline Hedging Activity & 0.17 & 0.19 & 0.17 & 0.18 \\
\hline Market Size & 1,049 & 1,596 & 1,048 & 1,349 \\
\hline Total Assets & 3,048 & 6,324 & 3,081 & 6,448 \\
\hline R\&D Activity & 0.02 & 0.05 & 0.01 & 0.02 \\
\hline
\end{tabular}


Table 2-A Commodity-Industry Matches Using the Statistical and Modified Statistical Methods

The table displays the commodities matched to industries using the statistical method and constrained statistical method. To determine the matches we use out-of-sample US firms that are in the lowest quartile of stock market capitalization at the beginning of each month in each industry. The following commodities, that are priced globally, and return series that are available in Datastream are considered: Gold (GOLDBLN), Silver (SILVERH), Aluminum (LAHCASH), Copper (LCPCASH), Nickel (LNICASH), Zinc (LZZCASH), Lead (LEDCASH), Tin(LTICASH), Crude Oil (CRUDWTC), Corn(CORNUS2), Wheat (WHEATSF), Lumber (LUMRLF1), Feeder Cattle (CFCINDX), Lean Hog Index (CLHINDX), Cotton (COTTONM), Soybean (SOYBEAN), Cacao (COCINUS), Coffee (COFDICA), Sugar (WSUGDLY).

Statistical Matching

\begin{tabular}{|c|c|c|}
\hline $\begin{array}{l}\text { FF-30 } \\
\text { Industry }\end{array}$ & $\begin{array}{l}\text { FF-30 Industry } \\
\text { Description }\end{array}$ & $\begin{array}{l}\text { Matched } \\
\text { Commodity }\end{array}$ \\
\hline 1 & Food Products & None \\
\hline
\end{tabular}

\begin{tabular}{cll}
\hline 4 & Recreation & Feeder Cattle \\
\hline 8 & Healthcare, Medical & Feeder Cattle \\
& $\begin{array}{l}\text { Eqt, Pharmaceutical } \\
\text { Products }\end{array}$ \\
\hline 11 & $\begin{array}{l}\text { Construction \& } \\
\text { Construction Materials }\end{array}$ \\
\hline 12 & $\begin{array}{l}\text { Steel Works (Metals) } \\
\text { Etc. }\end{array}$ & Silver \\
\hline 13 & $\begin{array}{l}\text { Fabricated Prod.s \& } \\
\text { Machinery }\end{array}$ & Feeder Cattle \\
\hline 17 & $\begin{array}{l}\text { Precious Metals, Non- Gold } \\
\text { Metallic, \& Industrial } \\
\\
\text { Metal Mining }\end{array}$ \\
\end{tabular}

\begin{tabular}{cll}
\hline 19 & Petroleum and N. Gas & Crude Oil \\
\hline 21 & Communication & Feeder Cattle \\
\hline 22 & $\begin{array}{l}\text { Personal \& Bus. } \\
\text { Services }\end{array}$ & Crude Oil \\
\hline 23 & Business Equipment & Crude Oil \\
\hline 25 & Transportation & Feeder Cattle \\
\hline 26 & Wholesale & Lead \\
\hline 27 & Retail & Feeder Cattle
\end{tabular}

\section{Constrained Statistical Matching}

\begin{tabular}{|c|c|c|}
\hline $\begin{array}{l}\text { SIC 4 } \\
\text { Industry }\end{array}$ & $\begin{array}{l}\text { SIC } 4 \text { Industry } \\
\text { Description }\end{array}$ & $\begin{array}{l}\text { Matched } \\
\text { Commodity }\end{array}$ \\
\hline $100-199$ & Agric prod.- crops & Corn \\
\hline $200-299$ & Agric prod. - livestock & Feeder Cattle \\
\hline 2010-2019 & Meat Products & der Cattle \\
\hline 2040-2046 & Flour \& O. Grain Mill & Wheat \\
\hline $2050-2059$ & Bakery Products & Wheat \\
\hline $2060-2063$ & Sugar \& Confectionery & Sugar \\
\hline 2095 & Roasted Coffee & Coffee \\
\hline
\end{tabular}

None

None

2400-2439 Lumber \& Wood P. Lumber

All Silver

None

\begin{tabular}{lll}
\hline 1020-1029 & Copper Ores & Copper \\
1030-1039 & Lead \& Zinc Ores & Zinc \\
1050-1059 & Bauxite \& Alumin. O. & Aluminum \\
1040-1049 & Gold \& Silver Ores & Gold \\
All others & Gold \\
\hline All & Crude Oil \\
\hline None & \\
\hline None & \\
\hline None & \\
\hline None & \\
\hline None & \\
\hline $5210-5219$ & Lumber \& Bldg.Mat. & Lumber \\
\hline
\end{tabular}




\section{Table 2B Commodity-Industry Matches Using the BEA Data}

The table lists industries at the I-O 6 digit code level matched with commodities by utilizing the "industry commodity use table (2002)" from the BEA website. Primary industries are in italics.

\begin{tabular}{|c|c|c|}
\hline $\begin{array}{l}\text { I-O 6-Digit } \\
\text { Ind. Code }\end{array}$ & Industry Definition & $\begin{array}{c}\text { Matching } \\
\text { Commodity }\end{array}$ \\
\hline $31161 \mathrm{~A}$ & Animal (except poultry) slaughtering, rendering, and processing & Feeder Cattle \\
\hline 111335 & Tree nut farming & Feeder Cattle \\
\hline $1113 \mathrm{~A} 0$ & Fruit farming & Feeder Cattle \\
\hline 112120 & Dairy cattle and milk production & Feeder Cattle \\
\hline 115000 & Support activities for agriculture and forestry & Feeder Cattle \\
\hline $31151 \mathrm{~A}$ & Fluid milk and butter manufacturing & Feeder Cattle \\
\hline $1121 \mathrm{~A} 0$ & Cattle ranching and farming & Feeder Cattle \\
\hline 311514 & Dry, condensed, and evaporated dairy product manufacturing & Feeder Cattle \\
\hline 316100 & Leather and hide tanning and finishing & Feeder Cattle \\
\hline 311410 & Frozen food manufacturing & Feeder Cattle \\
\hline 311513 & Cheese manufacturing & Feeder Cattle \\
\hline 111200 & Vegetable and melon farming & Feeder Cattle \\
\hline 311520 & Ice cream and frozen dessert manufacturing & Feeder Cattle \\
\hline $112 \mathrm{~A} 00$ & Animal production, except cattle and poultry and eggs & Lean Hog Index \\
\hline 311320 & Chocolate and confectionery manufacturing from cacao beans & Cacao \\
\hline 311920 & Coffee and tea manufacturing & Coffee \\
\hline 311210 & Flour milling and malt manufacturing & Corn \\
\hline 311615 & Poultry processing & Corn \\
\hline 112300 & Poultry and egg production & Corn \\
\hline 311221 & Wet corn milling & Corn \\
\hline 311830 & Tortilla manufacturing & Corn \\
\hline 311119 & Other animal food manufacturing & Corn \\
\hline 311111 & Dog and cat food manufacturing & Corn \\
\hline 1111B0 & Grain farming & Corn \\
\hline 313240 & Knit fabric mills & Cotton \\
\hline 111920 & Cotton farming & Cotton \\
\hline 313100 & Fiber, yarn, and thread mills & Cotton \\
\hline 314110 & Carpet and rug mills & Cotton \\
\hline 486000 & Pipeline transportation & Crude Oil \\
\hline 213112 & Support activities for oil and gas operations & Crude Oil \\
\hline 325182 & Carbon black manufacturing & Crude Oil \\
\hline 221200 & Natural gas distribution & Crude Oil \\
\hline 114100 & Fishing & Crude Oil \\
\hline 311700 & Seafood product preparation and packaging & Crude Oil \\
\hline 481000 & Air transportation & Crude Oil \\
\hline 324121 & Asphalt paving mixture and block manufacturing & Crude Oil \\
\hline 324110 & Petroleum refineries & Crude Oil \\
\hline 325130 & Synthetic dye and pigment manufacturing & Crude Oil \\
\hline 561700 & Services to buildings and dwellings & Crude Oil \\
\hline 324191 & Petroleum lubricating oil and grease manufacturing & Crude Oil \\
\hline 325181 & Alkalies and chlorine manufacturing & Crude Oil \\
\hline
\end{tabular}


213111

335991

325310

211000

324199

324122

325910

2122A0

335911

331419

33131A

332430

312110

331314

331520

336212

33131B

331420

335920

331411

337110

32121B

321100

321999

33721A

322110

113A00

321920

321992

337122

321219

321910

32121A

113300

212230

$1111 \mathrm{~A} 0$

311225

31122A

1119B0

311910

311940

311313

1119A0

31131A
Drilling oil and gas wells

Crude Oil

Carbon and graphite product manufacturing

Crude Oil

Fertilizer manufacturing

Crude Oil

Oil and gas extraction

All other petroleum and coal products manufacturing

Crude Oil

Crude Oil

Asphalt shingle and coating materials manufacturing

Crude Oil

Printing ink manufacturing

Gold, silver, and other metal ore mining

Crude Oil

Gold

Gold

Storage battery manufacturing

Gold

Alumina refining and primary aluminum production

Metal can, box, and other metal container (light gauge) manufacturing

Soft drink and ice manufacturing

Secondary smelting and alloying of aluminum

Nonferrous metal foundries

Truck trailer manufacturing

Aluminum product manufacturing from purchased aluminum

Copper rolling, drawing, extruding and alloying

Communication and energy wire and cable manufacturing

Primary smelting and refining of copper

Wood kitchen cabinet and countertop manufacturing

Engineered wood member and truss manufacturing

Sawmills and wood preservation

All other miscellaneous wood product manufacturing

Wood television, radio, and sewing machine cabinet manufacturing

Pulp mills

Forest nurseries, forest products, and timber tracts

Wood container and pallet manufacturing

Prefabricated wood building manufacturing

Non-upholstered wood household furniture manufacturing

Reconstituted wood product manufacturing

Wood windows and doors and millwork

Veneer and plywood manufacturing

Logging

Copper, nickel, lead, and zinc mining

Oilseed farming

Fats and oils refining and blending

Soybean and other oilseed processing

All other crop farming

Snack food manufacturing

Seasoning and dressing manufacturing

Beet sugar manufacturing

Sugarcane and sugar beet farming

Sugar cane mills and refining
Aluminum

Aluminum

Aluminum

Aluminum

Aluminum

Aluminum

Aluminum

Copper

Copper

Copper

Lumber

Lumber

Lumber

Lumber

Lumber

Lumber

Lumber

Lumber

Lumber

Lumber

Lumber

Lumber

Lumber

Lumber

Zinc

Soybean

Soybean

Soybean

Wheat

Wheat

Wheat

Sugar

Sugar

Sugar 


\section{Table 3: Incorporation of Idiosyncratic Information into Stock Prices}

The Table reports mean coefficients from Fama-MacBeth cross-section regressions, run separately for each of 1,095 weeks. Industries are matched to commodities using the statistical matching in regressions 3.1 and 3.2, modified statistical matching in regression 3.3 and 3.4 and BEA matching in regressions 3.5 and 3.6. US firms are excluded from the sample in the first 4 regressions as they are used to identify the industry-commodity links. US firms are included in the sample in regressions 3.5 and 3.6. The dependent variable is the weekly idiosyncratic stock return in local currency, measured from Wednesday to Wednesday. Coefficients are multiplied by 100 . The numbers in parentheses are p-values. Significance levels of means of coefficients from weekly cross-sectional regressions are adjusted for potential autocorrelation using Newey-West methodology with 4 lags. Boldface indicates coefficients significant at $10 \%$ or better in two-tailed tests.

\begin{tabular}{|c|c|c|c|c|c|c|}
\hline & Statistica & Matching & $\begin{array}{r}\text { Constrain } \\
\mathrm{Ma}\end{array}$ & $\begin{array}{l}\text { Statistical } \\
\text { hing }\end{array}$ & BEA N & atching \\
\hline & 3.1 & 3.2 & 3.3 & 3.4 & 3.5 & 3.6 \\
\hline $\begin{array}{l}\text { Idiosyncratic Commodity } \\
\text { Return }\end{array}$ & $\begin{array}{c}5.82 \\
(0.00)\end{array}$ & & $\begin{array}{c}7.11 \\
(0.00)\end{array}$ & & $\begin{array}{r}2.54 \\
(0.00)\end{array}$ & \\
\hline Group Affiliated Firm & $\begin{array}{c}0.06 \\
(0.01)\end{array}$ & $\begin{array}{c}0.06 \\
(0.00)\end{array}$ & $\begin{array}{c}0.14 \\
(0.00)\end{array}$ & $\begin{array}{c}0.09 \\
(0.01)\end{array}$ & $\begin{array}{c}0.04 \\
(0.14)\end{array}$ & $\begin{array}{c}0.02 \\
(0.51)\end{array}$ \\
\hline $\begin{array}{l}\text { Idiosyncratic Commodity } \\
\text { Return * Group Affiliated } \\
\text { Firm }\end{array}$ & $\begin{array}{l}-2.46 \\
(0.01)\end{array}$ & $\begin{array}{l}-1.84 \\
(0.04)\end{array}$ & $\begin{array}{l}-1.85 \\
(0.02)\end{array}$ & $\begin{array}{l}-1.91 \\
(0.07)\end{array}$ & $\begin{array}{l}-1.64 \\
(0.03)\end{array}$ & $\begin{array}{l}-1.90 \\
(0.03)\end{array}$ \\
\hline Intercept & $\begin{array}{l}-0.03 \\
(0.29)\end{array}$ & & $\begin{array}{r}-0.09 \\
0.06\end{array}$ & & $\begin{array}{l}-0.04 \\
(0.18)\end{array}$ & \\
\hline $\begin{array}{l}\text { Economy*Industry Fixed } \\
\text { Effects }\end{array}$ & No & Yes & No & Yes & No & Yes \\
\hline Firm*Week Observations & $5,767,175$ & $5,767,175$ & $1,491,947$ & $1,491,947$ & $1,057,725$ & $1,057,725$ \\
\hline Number of Economies & 42 & 42 & 42 & 42 & 43 & 43 \\
\hline Average Adj. $\mathrm{R}^{2}$ & 0.01 & 0.05 & 0.01 & 0.04 & 0.01 & 0.11 \\
\hline
\end{tabular}




\section{Table 4: Group Affiliation vs. Other Firm Level Characteristics}

The Table revisits mean coefficients from Fama-MacBeth cross-section regressions 3.2 of Table 3, run separately for each of 1,095 weeks, but including additional control variables and their interactions with the group affiliation indicator. Dependent variable is firm-specific stock return in local currency, measured Wednesday to Wednesday, for stocks in 42 economies. Coefficients are multiplied by 100 . Numbers in parentheses are p-values, adjusted for time series autocorrelation of 4 weeks in successive cross-section estimates using Newey-West methodology. Boldface indicates mean coefficients significant at $10 \%$ or better in 2-tailed tests.

\begin{tabular}{|c|c|c|c|c|c|c|c|}
\hline & 4.1 & 4.2 & 4.3 & 4.4 & 4.5 & 4.6 & 4.7 \\
\hline $\begin{array}{l}\text { Idiosyncratic Commodity } \\
\text { Return } * \text { Group Affiliated Firm }\end{array}$ & $\begin{array}{l}-1.87 \\
(0.04)\end{array}$ & $\begin{array}{l}-1.69 \\
(0.06)\end{array}$ & $\begin{array}{l}-1.81 \\
(0.04)\end{array}$ & $\begin{array}{l}-1.79 \\
(0.05)\end{array}$ & $\begin{array}{l}-1.86 \\
(0.04)\end{array}$ & $\begin{array}{l}-1.95 \\
(0.03)\end{array}$ & $\begin{array}{l}-1.80 \\
(0.05)\end{array}$ \\
\hline $\begin{array}{l}\text { Idiosyncratic Commodity } \\
\text { Return * Diversification }\end{array}$ & $\begin{array}{c}0.94 \\
(0.59)\end{array}$ & & & & & & $\begin{array}{c}0.51 \\
(0.74)\end{array}$ \\
\hline $\begin{array}{l}\text { Idiosyncratic Commodity } \\
\text { Return * Leverage }\end{array}$ & & $\begin{array}{l}-3.01 \\
(0.15)\end{array}$ & & & & & $\begin{array}{l}-4.35 \\
(0.04)\end{array}$ \\
\hline $\begin{array}{l}\text { Idiosyncratic Commodity } \\
\text { Return } * \text { Hedging Activity }\end{array}$ & & & $\begin{array}{l}1.58 \\
(0.37)\end{array}$ & & & & $\begin{array}{c}1.66 \\
(0.37)\end{array}$ \\
\hline $\begin{array}{l}\text { Idiosyncratic Commodity } \\
\text { Return * Log Market Size }\end{array}$ & & & & $\begin{array}{c}0.66 \\
(0.13)\end{array}$ & & & $\begin{array}{c}0.69 \\
(0.09)\end{array}$ \\
\hline $\begin{array}{l}\text { Idiosyncratic Commodity } \\
\text { Return } * \text { Log Total Assets }\end{array}$ & & & & & $\begin{array}{c}0.20 \\
(0.57)\end{array}$ & & \\
\hline $\begin{array}{l}\text { Idiosyncratic Commodity } \\
\text { Return * R\&D Activity }\end{array}$ & & & & & & $\begin{array}{l}-28.2 \\
(0.23)\end{array}$ & $\begin{array}{l}-33.0 \\
(0.17)\end{array}$ \\
\hline Group Affiliated Firm & $\begin{array}{c}0.06 \\
(\mathbf{0 . 0 0})\end{array}$ & $\begin{array}{c}0.06 \\
(\mathbf{0 . 0 0})\end{array}$ & $\begin{array}{c}0.06 \\
(\mathbf{0 . 0 0})\end{array}$ & $\begin{array}{c}0.06 \\
(\mathbf{0 . 0 0})\end{array}$ & $\begin{array}{c}0.05 \\
(\mathbf{0 . 0 0})\end{array}$ & $\begin{array}{c}0.06 \\
(\mathbf{0 . 0 0})\end{array}$ & $\begin{array}{c}0.06 \\
(\mathbf{0 . 0 0})\end{array}$ \\
\hline Diversification & $\begin{array}{l}-0.01 \\
(0.81)\end{array}$ & & & & & & $\begin{array}{l}\mathbf{- 0 . 0 6} \\
(0.04)\end{array}$ \\
\hline Leverage & & $\begin{array}{c}0.19 \\
(0.00)\end{array}$ & & & & & $\begin{array}{c}0.15 \\
(\mathbf{0 . 0 1})\end{array}$ \\
\hline Hedging Activity & & & $\begin{array}{l}-0.03 \\
(0.31)\end{array}$ & & & & $\begin{array}{c}1.66 \\
(0.36)\end{array}$ \\
\hline Log Market Size & & & & $\begin{array}{l}-\mathbf{- 0 . 0 7} \\
(\mathbf{0 . 0 0})\end{array}$ & & & $\begin{array}{c}-\mathbf{- 0 . 0 8} \\
(\mathbf{0 . 0 0})\end{array}$ \\
\hline Log Total Assets & & & & & $\begin{array}{l}-\mathbf{- 0 . 0 2} \\
(\mathbf{0 . 0 5})\end{array}$ & & \\
\hline R\&D Activity & & & & & & $\begin{array}{c}0.03 \\
(0.96)\end{array}$ & $\begin{array}{c}0.28 \\
(0.60)\end{array}$ \\
\hline $\begin{array}{l}\text { Economy*Industry Fixed } \\
\text { Effects }\end{array}$ & Yes & Yes & Yes & Yes & Yes & Yes & Yes \\
\hline Average Adj. $\mathrm{R}^{2}$ & 0.05 & 0.05 & 0.05 & 0.05 & 0.05 & 0.05 & 0.06 \\
\hline
\end{tabular}




\section{Table 5. Firms Changing Group Affiliation Status}

The table reports a difference-in-differences analysis of changes in the sensitivity of firm-specific stock returns to commodity price shocks. The treatment group consists of firms experiencing a change in affiliation status between year $t-1$ and year $t+1$, by either becoming group affiliated (positive treatment) or ceasing to be affiliated to a business group (negative treatment). Group affiliates have a controlling shareholder with a block of $20 \%$ or more; unaffiliated firms do not. Block acquisitions or sales that change firms' group affiliation status must be for at least $5 \%$ of the firm's shares. The firm's group affiliation must be stable going forward 1 year. The difference (third column) is the sensitivity of firms' firm-specific stock returns to commodity shocks after the change in group affiliation status minus that before the change in status. The matched group is firms that did not experience a change in group affiliation status and that are in the same economy-industry selected using the nearest neighbor matching on total assets, leverage, $\mathrm{R} \& \mathrm{D}$ expenses/total assets and commodity beta in the year prior to the event. The sample includes all economies. Coefficients are multiplied by 100 . When both positive and negative treated observations are pooled, the difference-in-differences coefficients of negatively treated observations are multiplied by -1 . Industry-commodity matching is by statistical method. The left hand side variable is winsorized at the $5 \%$ level. Boldface indicates coefficients significance at $10 \%$ or better in two-tailed tests.

\begin{tabular}{|c|c|c|c|c|}
\hline & Beta Before & Beta After & Difference & $\begin{array}{c}\text { Difference } \\
\text { in differences }\end{array}$ \\
\hline \multicolumn{5}{|c|}{ Positive Treatment (Unaffiliated Transition to Affiliated) } \\
\hline Treated (Transition) Firms & $\begin{array}{c}7.46 \\
(0.00)\end{array}$ & $\begin{array}{c}3.50 \\
(0.00)\end{array}$ & $\begin{array}{l}-3.96 \\
(0.00)\end{array}$ & $\begin{array}{c}-3.76 \\
(0.03)\end{array}$ \\
\hline Matched Firms & $\begin{array}{c}6.65 \\
(0.00)\end{array}$ & $\begin{array}{c}6.46 \\
(0.00)\end{array}$ & $\begin{array}{l}-0.19 \\
(0.89)\end{array}$ & \\
\hline Number of Observations & 2,855 & 2,855 & 2,855 & 2,855 \\
\hline \multicolumn{5}{|c|}{ Negative Treatment (Affiliated Transition to Unaffiliated) } \\
\hline Treated (Transition) Firms & $\begin{array}{c}6.35 \\
(\mathbf{0 . 0 0})\end{array}$ & $\begin{array}{c}9.22 \\
(0.00)\end{array}$ & $\begin{array}{c}\mathbf{2 . 8 8} \\
(\mathbf{0 . 0 7})\end{array}$ & $\begin{array}{c}3.33 \\
(\mathbf{0 . 0 8})\end{array}$ \\
\hline Matched Firms & $\begin{array}{c}6.34 \\
(0.00)\end{array}$ & $\begin{array}{c}5.89 \\
(0.00)\end{array}$ & $\begin{array}{l}-0.45 \\
(0.76)\end{array}$ & \\
\hline Number of Observations & 2,302 & 2,302 & 2,302 & 2,302 \\
\hline \multicolumn{5}{|c|}{ Pooled Positive and Sign Inverted Negative Treatment } \\
\hline Treated (Transition) Firms & & & $\begin{array}{l}-3.47 \\
(\mathbf{0 . 0 0})\end{array}$ & $\begin{array}{c}-3.57 \\
(\mathbf{0 . 0 0})\end{array}$ \\
\hline Matched Firms & & & $\begin{array}{c}0.09 \\
(0.93)\end{array}$ & \\
\hline Number of Observations & & & 5,157 & 5,157 \\
\hline
\end{tabular}




\section{Table 6. Targets of Successful Control Block Bids versus Bids that Failed Due to Plausibly Exogenous Reasons}

The table reports a difference-in-differences analysis of changes in idiosyncratic stock returns' beta with respect to idiosyncratic commodity shocks. The treated group consists of targets of successful control block acquisitions, where targets were unaffiliated in the year prior to the bid announcement, which left the acquirer owning $20 \%$ or more of the target's shares after the transaction. The matched group consists of targets of similar bids that failed for plausibly exogenous reasons. The targets were unaffiliated in the year prior to the bid announcement and the acquirer sought to own at least $20 \%$ of the target's shares after the transaction. Firms in the matched group are selected using nearest neighbor matching criteria based on total assets, leverage, and R\&D expenses/total assets and commodity beta in the year prior to the acquisition or failed acquisition attempt, and are, when possible, from the same economy-industryyear as each target of successful bid. The sample includes all economies. Industry-commodity matching is by the statistical method. Coefficients are multiplied by 100. The dependent variable is winsorized at the $5 \%$ level. Boldface indicates coefficients significance at $10 \%$ or better in two-tailed tests.

\begin{tabular}{|c|c|c|c|c|}
\hline Firm-specific stock return sensitivity of commodity price & $\begin{array}{c}52 \\
\text { weeks } \\
\text { before }\end{array}$ & $\begin{array}{c}52 \\
\text { weeks } \\
\text { after }\end{array}$ & Difference & $\begin{array}{l}\text { Difference } \\
\text { in } \\
\text { differences }\end{array}$ \\
\hline Treated Firms & $\begin{array}{c}4.99 \\
(0.00)\end{array}$ & $\begin{array}{c}0.61 \\
(0.71)\end{array}$ & $\begin{array}{l}-4.38 \\
(0.02)\end{array}$ & $\begin{array}{l}-6.65 \\
(0.00)\end{array}$ \\
\hline Matched Firms & $\begin{array}{c}4.70 \\
(0.00)\end{array}$ & $\begin{array}{c}6.97 \\
(0.00)\end{array}$ & $\begin{array}{c}2.28 \\
(0.01)\end{array}$ & \\
\hline Observations & 5,284 & 5,284 & 5,284 & 5,284 \\
\hline
\end{tabular}




\section{Table 7. Within Group Transmission of Commodity Shocks}

The table tests whether a firm's stock price reacts to commodity shocks to other firms within the same business group that matches with a commodity other than the firm's own matched commodity. For this exercise we use a sample of firms that belong to the same business group, i.e. have a common controlling shareholder, such that at least two firms of the group are in our sample and at least one of the firms matches with a different commodity than matched commodities of other group firms. In regression 7.4, we only include cases that a group firm's industry beta does not statistically significantly load on the commodity shocks in regression [3c], i.e. we require the absolute value of t-statistics of beta to be less than 0.5 when commodities are entered individually. The dependent variable is the weekly idiosyncratic stock return in local currency, measured from Wednesday to Wednesday. Coefficients are multiplied by 100 . The numbers in parentheses are p-values. Estimation is by weekly Fama-MacBeth regressions in regressions 7.1-7.3 and monthly in 7.4. In regression 7.4 low number of observations results in few extreme coefficients when Fama-Macbeth regressions are run for each week; in this case the average coefficient of idiosyncratic commodity shocks to other group firms is 6.2 and $p=0.04$. We adjust standard errors for time series autocorrelation of 4 weeks using the Newey-West methodology. Boldface indicates coefficients significance at $10 \%$ or better in two-tailed tests.

\begin{tabular}{|c|c|c|c|c|}
\hline & 7.1 & 7.2 & 7.3 & 7.4 \\
\hline Sample & All & All & $\begin{array}{c}\text { Top 25\% Shocks } \\
\text { to Other Group } \\
\text { Firms } \\
\end{array}$ & $\begin{array}{c}\text { Non-sensitive } \\
\text { industry- } \\
\text { commodity pairs }\end{array}$ \\
\hline $\begin{array}{l}\text { Idiosyncratic Commodity } \\
\text { Shocks to Other Group Firms }\end{array}$ & $\begin{array}{c}0.86 \\
(0.04)\end{array}$ & $\begin{array}{c}0.70 \\
(0.10)\end{array}$ & $\begin{array}{c}1.12 \\
(\mathbf{0 . 0 2})\end{array}$ & $\begin{array}{c}2.52 \\
(0.08)\end{array}$ \\
\hline $\begin{array}{l}\text { Own Idiosyncratic Commodity } \\
\text { Shocks }\end{array}$ & & $\begin{array}{c}3.80 \\
(0.00)\end{array}$ & $\begin{array}{c}2.60 \\
(0.11)\end{array}$ & \\
\hline Intercept & $\begin{array}{l}-0.01 \\
(0.44)\end{array}$ & $\begin{array}{l}-0.01 \\
(0.59)\end{array}$ & $\begin{array}{l}-0.02 \\
(0.33)\end{array}$ & $\begin{array}{l}-0.01 \\
(0.84)\end{array}$ \\
\hline Firm*Week Observations & 735,014 & 735,014 & 188,636 & 39,943 \\
\hline Average Adj. $\mathrm{R}^{2}$ & 0.01 & 0.02 & 0.02 & 0.00 \\
\hline
\end{tabular}




\section{Table 8: Robustness Tests}

We repeat the test in regression 3.2 of Table 3 using alternative methods and samples. Regression 8.1 modifies the statistically matching as described in Appendix Table A5. Regression 8.2 drops group affiliated firms that control other firms in the sample. In 8.3 we use a $15 \%$ threshold to presume control and. Regression 8.4 excludes Japan and the UK from the sample. These two economies have the largest number of observations in the sample that already excludes the US. Regression 8.5 limits the time period to the latest 10 years. Regression 8.6 uses panel data regression instead of Fama-MacBeth. Regression 8.7 uses local market returns and Fama-French global 5 factors to estimate the idiosyncratic component of stock and commodity returns. Coefficients were multiplied by 100. The numbers in parentheses are p-values. When we use Fama-MacBeth regressions we adjust the standard errors for time series autocorrelation of 4 weeks using the Newey-West methodology. Boldface indicates coefficients significance at $10 \%$ or better in two-tailed tests.

\begin{tabular}{|c|c|c|c|c|c|c|c|}
\hline & 8.1 & 8.2 & 8.3 & 8.4 & 8.5 & 8.6 & 8.7 \\
\hline & $\begin{array}{l}\text { Statistical and } \\
\text { Economic } \\
\text { Significance }\end{array}$ & $\begin{array}{l}\text { Group Firms at } \\
\text { the Bottom of } \\
\text { Ownership } \\
\text { Pyramid }\end{array}$ & $\begin{array}{l}15 \% \text { Threshold } \\
\text { for Control }\end{array}$ & $\begin{array}{l}\text { Exclude Japan } \\
\text { \& UK }\end{array}$ & $\begin{array}{l}\text { Time Period: } \\
\text { 2003-2013 }\end{array}$ & $\begin{array}{l}\text { Panel } \\
\text { Regression }\end{array}$ & $\begin{array}{l}\text { Fama-French } 5 \\
\text { Factor model }\end{array}$ \\
\hline Group Affiliated Firm & $\begin{array}{c}\mathbf{0 . 0 7} \\
(\mathbf{0 . 0 0 )}\end{array}$ & $\begin{array}{c}0.06 \\
(0.00)\end{array}$ & $\begin{array}{c}0.06 \\
(0.00)\end{array}$ & $\begin{array}{c}0.06 \\
(0.02)\end{array}$ & $\begin{array}{c}\mathbf{0 . 0 7} \\
(\mathbf{0 . 0 0})\end{array}$ & $\begin{array}{c}\mathbf{0 . 0 4} \\
(\mathbf{0 . 0 0})\end{array}$ & $\begin{array}{c}0.02 \\
(0.27)\end{array}$ \\
\hline $\begin{array}{c}\text { Idiosyncratic Commodity Return * } \\
\text { Group Affiliated Firm }\end{array}$ & $\begin{array}{l}-1.29 \\
(0.05)\end{array}$ & $\begin{array}{l}-1.81 \\
(0.05)\end{array}$ & $\begin{array}{l}-2.22 \\
(0.02)\end{array}$ & $\begin{array}{l}-2.40 \\
(0.04)\end{array}$ & $\begin{array}{l}-1.85 \\
(0.07)\end{array}$ & $\begin{array}{l}-0.98 \\
(0.00)\end{array}$ & $\begin{array}{l}-2.48 \\
(0.01)\end{array}$ \\
\hline $\begin{array}{c}\text { Economy*Industry*Time Fixed } \\
\text { Effects }\end{array}$ & Yes & Yes & Yes & Yes & Yes & Yes & Yes \\
\hline Firm*Week Observations & $6,624,689$ & $5,755,866$ & $5,753,487$ & $4,180,231$ & $4,864,415$ & $5,767,175$ & $5,781,727$ \\
\hline Number of Economies & 42 & 42 & 42 & 40 & 42 & 42 & 42 \\
\hline Number of Weeks & 1,095 & 1,095 & 1,095 & 1,095 & 574 & 1095 & 1095 \\
\hline
\end{tabular}




\section{Table 9. R-squared Around the World}

The dependent variable is a logistic transformation of the R-squared (i.e., $\mathrm{Y}=\log (\mathrm{R} 2 /(1-\mathrm{R} 2))$ from annual firm level regressions based on equation [1]. Results summarizes Fama-MacBeth regressions for each year, adjusting for time series autocorrelation over 10 years using the Newey-West methodology. Numbers in parentheses are p-values. Boldface indicates coefficients significance at $10 \%$ or better in twotailed tests.

\begin{tabular}{|c|c|c|c|c|}
\hline & 9.1 & 9.2 & 9.3 & 9.4 \\
\hline Log GDP per Capita & $\begin{array}{l}-0.14 \\
(0.03)\end{array}$ & & $\begin{array}{l}-\mathbf{- 0 . 1 3} \\
(\mathbf{0 . 0 3})\end{array}$ & $\begin{array}{l}-\mathbf{- 0 . 1 5} \\
(0.01)\end{array}$ \\
\hline Group Affiliated Firm & & $\begin{array}{c}0.09 \\
(0.02)\end{array}$ & $\begin{array}{c}0.06 \\
(0.02)\end{array}$ & $\begin{array}{c}\text { 0.08 } \\
(\mathbf{0 . 0 0})\end{array}$ \\
\hline Property Rights & & & & $\begin{array}{c}0.00 \\
(0.94)\end{array}$ \\
\hline Accounting Standards & & & & $\begin{array}{c}0.00 \\
(0.17)\end{array}$ \\
\hline Intercept & $\begin{array}{c}0.82 \\
(0.20)\end{array}$ & $\begin{array}{c}-0.62 \\
(0.00)\end{array}$ & $\begin{array}{c}0.74 \\
(0.21)\end{array}$ & $\begin{array}{c}0.57 \\
(0.10)\end{array}$ \\
\hline Number of Firm*Years & 321,875 & 321,875 & 321,875 & 299,276 \\
\hline Average Adj. $\mathrm{R}^{2}$ & 0.02 & 0.01 & 0.02 & 0.02 \\
\hline
\end{tabular}




\section{Figure 1. Stock Return Co-movement, Economic Development, and the Importance of Business Groups}

The $R^{2}$ s statistic is from Morck et al. (2013) averaged across 1995-2010. GDP per capita is in current US dollars and from World Economic Outlook dataset from the IMF website and averaged across all sample years. Fraction of group affiliated observations (incidence of business groups) is from Table 1. The sample is 40 countries that are both in Morck et al. (2013) and in Table 1.

\section{Panel A. $R^{2}$ (vertical axis) versus per capita GDP}

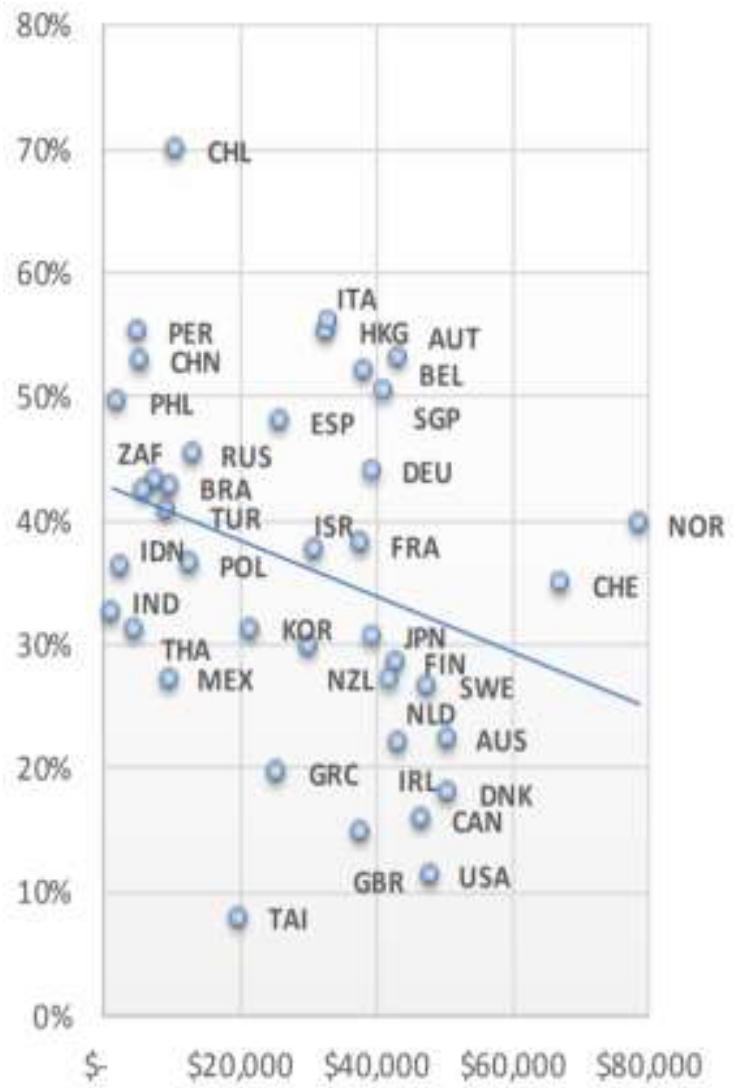

Panel B. The incidence of business groups (vertical axis) versus per capita GDP

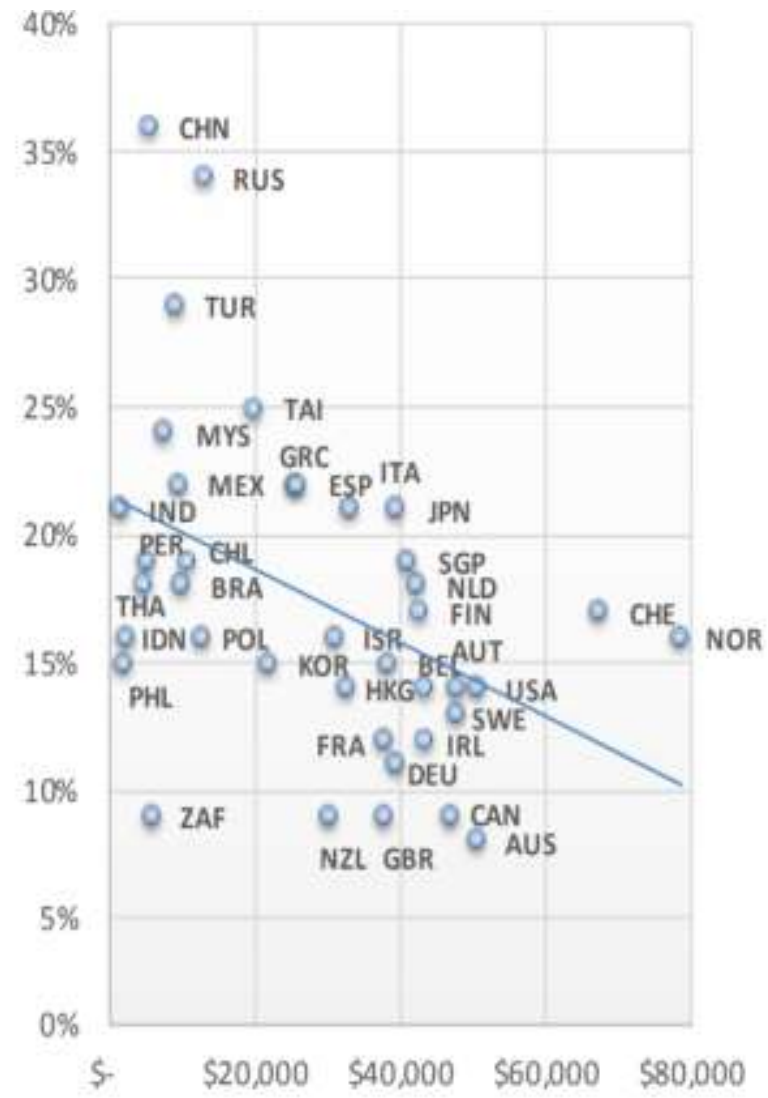

Panel C. $R^{2}$ (vertical axis) versus incidence of business groups

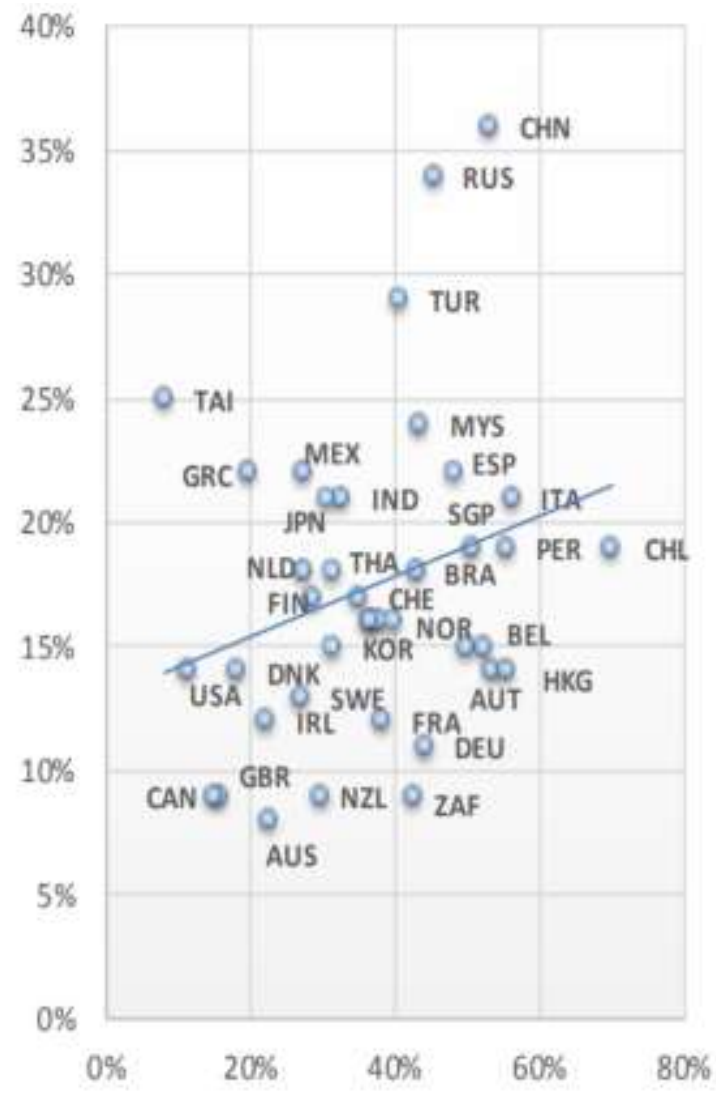

